\title{
Review on Life Cycle Assessment of Solar Photovoltaic Panels
}

\author{
Vincenzo Muteri ${ }^{1, *}$, Maurizio Cellura ${ }^{1}$, Domenico Curto ${ }^{1}\left[{ }^{(0)}\right.$, Vincenzo Franzitta ${ }^{1}(\mathbb{D}$, \\ Sonia Longo ${ }^{1}$, Marina Mistretta ${ }^{2}$ and Maria Laura Parisi ${ }^{3}$ (D) \\ 1 Department of Engineering, University of Palermo, Viale delle Scienze Ed.9, 90128 Palermo, Italy; \\ maurizio.cellura@unipa.it (M.C.); domenico.curto@unipa.it (D.C.); vincenzo.franzitta@unipa.it (V.F.); \\ sonia.longo@unipa.it (S.L.) \\ 2 Department of Heritage, Architecture, Urbanism (PAU)-University Mediterranea of Reggio Calabria, \\ Salita Melissari, 89124 Reggio Calabria, Italy; marina.mistretta@unirc.it \\ 3 R2ES Lab, Department of Biotechnology, Chemistry and Pharmacy, University of Siena, Via Aldo Moro 2, \\ 53100 Siena, Italy; marialaura.parisi@unisi.it \\ * Correspondence: vincenzo.muteri@unipa.it; Tel.: +39-0912-386-1977
}

Received: 9 December 2019; Accepted: 30 December 2019; Published: 3 January 2020

\begin{abstract}
The photovoltaic (PV) sector has undergone both major expansion and evolution over the last decades, and currently, the technologies already marketed or still in the laboratory/research phase are numerous and very different. Likewise, in order to assess the energy and environmental impacts of these devices, life cycle assessment (LCA) studies related to these systems are always increasing. The objective of this paper is to summarize and update the current literature of LCA applied to different types of grid-connected PV, as well as to critically analyze the results related to energy and environmental impacts generated during the life cycle of PV technologies, from 1st generation (traditional silicon based) up to the third generation (innovative non-silicon based). Most of the results regarded energy indices like energy payback time, cumulative energy demand, and primary energy demand, while environmental indices were variable based on different scopes and impact assessment methods. Moreover, the review work allowed to highlight and compare key parameters (PV type and system, geographical location, efficiency), methodological insights (functional unit, system boundaries, etc.), and energy/environmental hotspots of 39 LCA studies relating to different $\mathrm{PV}$ systems, in order to underline the importance of these aspects, and to provide information and a basis of comparison for future analyses.
\end{abstract}

Keywords: literature review; life cycle assessment (LCA); photovoltaic system (PV); environmental impacts; energy impacts; PV generations

\section{Introduction}

The solar photovoltaic (PV) market for electricity generation has developed strongly in the recent years. Based on last published data, 102.4 GW of grid-connected PV panels were installed globally in 2018, and this value corresponds to the total PV capacity available in the world in 2012 (100.9 GW). This result leads to a total global solar power capacity of more than $500 \mathrm{GW}$ in 2018 (solar world capacity installed had reached $400 \mathrm{GW}$ in 2017). The main contribution is given by China, United States, India, and Japan. With the exception of United States, where the new solar capacity installed was stable (10.6\% in 2017 and 2018), the other main contributors installed less than the previous year: China 44 GW (16\% less than 2017), India 8.3 GW (16\% less than 2017), and Japan 6.6 GW (8\% less than 2017). Australia was the world's fifth largest market in 2018, adding $5.3 \mathrm{GW}$, up to $295 \%$ more than $2017[1,2]$. 
The European Union (EU) assumed the leading role in achieving the final goals of the substitution of fossil fuels with renewable energies, the reduction of greenhouse gas (GHG) emissions and other environmental impacts due to their use. For this reason, according to the new $32 \%$ renewables target in 2030, the EU aims to extend the distribution of solar technology in the next years (in 2018, the total power installed in Europe was $11.3 \%$ GW, $21 \%$ more than the capacity installed in 2017). Considering the last year, the EU showed an important trend: 22 of $28 \mathrm{EU}$ markets showed an increase in the numbers of installation compared to 2017 and an overall growth of $8.2 \mathrm{GW}$ solar capacity connected to the grid (37\% more than 2017) [2]. A lot of effort was made to improve PV performances, also in the environmental field. Therefore, the PV technology is environmentally friendly compared to fossil fuel for many impact categories, but it cannot be considered totally free from environmental impacts during its life cycle.

Thus, the evaluation of the energy and environmental advantages of using PVs must be done, in consideration of the life cycles of these systems. A good standardized method to reach this goal is the life cycle assessment (LCA), which considers the environmental impacts, the primary renewable and non-renewable energy consumption, the resources depletion, and the emissions during the entire life cycle of a technology [3].

The LCA is an "objective procedure for assessing the energy and environmental loads related to a process or activity, carried out by identifying the energy and materials used, and the waste released into the environment" [4].

The aim of this paper is to contribute to update the current literature concerning LCA applied to different types of grid-connected PVs, up to the so-called third generation photovoltaic cells, through a review of the main studies related to this topic. In addition, the attention is focused on the key aspects and on the methodological insights related to the different studies.

The first section of this work is dedicated to a brief description of the main components of the PV devices. Then, a description of the different panel types available on the market and the most promising future alternatives is presented. The second part provides a review of analyzed publications about LCA applied to PV systems. The third part focuses on key aspects and methodological insights about the reviewed studies. The last section reports the conclusions.

\section{PV Technology Description}

Solar energy can be directly converted into electric energy by solar PV cells (or solar cells). These devices have practically zero emissions of pollutants during the operation phase, so they can be considered an optimal candidate for fossil fuels substitution into electricity production.

In the last decades, the interest in this technology was renewed, thanks to the significant reduction in the prices of photovoltaic cells and the global need to produce energy from renewable sources. Moreover, during recent years, there was an improvement in the production processes and the research for innovative materials has paved the way for new type of applications. These aspects are in line with the European energy strategy, which aims to provide in 2030, a $40 \%$ cut in greenhouse gas emissions compared to 1990 levels, at least a 32\% share of renewable energy consumption target, and an improvement in energy efficiency [5].

PV cells are electricity-producing devices that can differ in semiconductor materials, sizes and shapes. When many solar cells are electrically connected to each other and mounted on a support frame, they form a PV module. Multiple modules can be wired together to form an array. PV modules and arrays produce direct current (DC) electricity, and they're just one part of a PV system. It also includes [6]:

- Mounting structure: a stable and durable support that sustains PV modules and points panels toward the sun. This structure must protect the array from external agents, like wind, rain and moisture, and prevents corrosion over decades. Support systems are typically made of aluminum and are different depending on model and number of panels in the array; 
- Inverter: a component that converts the DC electricity produced by modules into alternating current (AC) electricity, which is used for local transmission of energy. This device needs to be replaced at least once in the lifetime of a PV array;

- Storage system: This is commonly used for stand-alone PV systems. Batteries are necessary for the storage of energy, especially for customers who cannot easily connect to the electric grid, because of geographical location or high cost of connecting to the grid. As outlined above, in this work, the authors only consider the grid-connected PV systems;

- Other components, which include components to connect all the parts together safely and securely, such as cables, connectors, and supports. At last, the combiner box is an essential part of a solar electric system that allows the connection of multiple solar modules in parallel.

The main components of a typical PV system, except the panels, are defined as the "balance of system" (BOS).

\section{Types of PV Cells}

The aim of continuous development of PV technology is to raise the performances of the cells, to reduce the market price of the modules, and to optimize the speed and cost of manufacturing processes.

Solar cells can be created with one single, or multiple layers of light-absorbing materials. In the first case, we refer to single junction cells, simple to manufacture but less efficient; conversely, the multiple configurations (multi-junctions) have various absorption and charge separation mechanisms, so they are more complex and higher performing [7]. PV systems can be distinguished based on the solar cell technology and materials. PV cells technologies are generally classified according three generations (Tables 1-3):

- The first generation includes the traditional panels with a crystalline silicon (c-Si) base structure, as single-crystalline silicon (sc-Si) and multi-crystalline silicon (mc-Si) cells;

- The second generation is based on the thin-film solar cells, which include amorphous silicon (a-Si), cadmium telluride (CdTe) and cadmium sulfide (CdS), copper indium gallium selenide (CIGS)/copper indium selenide (CIS), gallium arsenide (GaAs) and tandem/multi-junctions modules based on $\mathrm{Si}$;

- The third generation (also called next generation) encloses the innovative non-silicon based technologies and new concept devices as organic/semi-organic PV panels (OPV), perovskite solar cells (PSC), dye-sensitized solar cell (DSSC), and quantum dot (QD) cells.

The evolution through the various generations was dictated by the need to improve the cost/benefit ratio of PV technology [8]. Despite the progress, first generation PV has high production cost (between 200-500 US\$ $/ \mathrm{m}^{2}$ ) and there are little prospects that this value will drop further (until $150 \mathrm{US} \$ / \mathrm{m}^{2}$ ) [9], since more than half of the cost is due to the amount of material required and processes used [10]. Moreover, these manufacturing processes are, in most cases, energy intensive, and this has a significant effect on the life cycle emission factors of the devices. On the contrary, second generation offers low areal cost production (approximately between $30-110 \mathrm{US} \$ / \mathrm{m}^{2}$ ), by minimizing the quantity of material used and using low-cost manufacturing techniques (sputtering, vapor deposition, etc.), but the devices reach modest efficiency [11]. If second generation devices will achieve better efficiency performance to make their large-scale production competitive, this should lead to lower emission factors, since the manufacturing processes are less energy-consuming, compared to that of first generation. Finally, with the third generation, there is the possibility to increase the efficiency well beyond that of the first and second generations (through alternative mechanisms of energy conversion), and to reduce the production cost (approximately between $40-150$ US $\$ / \mathrm{m}^{2}$ for most efficient devices), thus maintaining the advantages of thin-film production techniques, both in energy and environmental terms. 
Table 1. First generation PV cells.

\begin{tabular}{|c|c|c|c|}
\hline \multicolumn{4}{|c|}{ 1st Generation PV Cells: Silicon Based Solar Cells (-Si) } \\
\hline \multicolumn{4}{|c|}{$\begin{array}{l}\text { Silicon is still the most common material used in PV modules, thanks to its excellent electronic, chemical and mechanical } \\
\text { properties [12]. Solar technologies based on this semiconductor are considered the most mature. In general, the fabrication of } \\
\text { silicon wafers is made through Czochralski (CZ) process. }\end{array}$} \\
\hline Type & Efficiency & Advantages & Disadvantages \\
\hline sc-Si & $\begin{array}{l}\text { - } 25-27 \% \text { in laboratory, the highest } \\
\text { efficiency compared with other } \\
\text { solar technologies [13] } \\
\text { - } \quad 16-22 \% \text { commercial efficiency } \\
\text { - } \quad \text { The band gap is } 1.11-1.15 \mathrm{eV} \\
\end{array}$ & $\begin{array}{l}\text { This type of solar panel } \\
\text { is the purest one and has } \\
\text { a high efficiency }\end{array}$ & $\begin{array}{l}\text { Manufacturing process }(\mathrm{CZ} \\
\text { process) is both material and } \\
\text { energy intensive }\end{array}$ \\
\hline mc-Si & $\begin{array}{ll}\text { - } & 15-18 \% \\
\text { - } & \text { The band gap is } 1.11 \mathrm{eV} \text { [14] }\end{array}$ & $\begin{array}{l}\text { A suitable alternative to } \\
\text { reduce PV module cost }\end{array}$ & Less efficient than sc-Si cells \\
\hline
\end{tabular}

Table 2. Second generation PV cells.

\begin{tabular}{|c|c|c|c|}
\hline \multicolumn{4}{|c|}{ Second Generation PV Cells: Thin Film Solar Cells (TFSCs) } \\
\hline \multicolumn{4}{|c|}{$\begin{array}{l}\text { Film layers thickness ranges from few nanometers }(\mathrm{nm}) \text { to tens of micrometers }(\mu \mathrm{m}) \text {. The main advantage of this technology is the low cost of } \\
\text { manufacturing and materials, due to the limited amount of semiconductor material required for each cell. Due to low thickness, TFSC are flexible, lower in } \\
\text { weight, and have less drag compared to first generation PV. TFSCs are made by the deposition of thin layers of certain materials on glass, plastic, or } \\
\text { stainless steel substrates using sputtering tools. Some of these technologies are not yet commercialized. }\end{array}$} \\
\hline Type & Efficiency & Advantages & Disadvantages \\
\hline $\mathrm{a}-\mathrm{Si}$ & $\begin{array}{l}\text { - } 4 \% \text { for modules placed } \\
\text { on the market } \\
\text { Small cells in lab can } \\
\text { reach } 12 \%[14]\end{array}$ & $\begin{array}{l}\text { a-Si solar cells are the cheapest on the } \\
\text { market }\end{array}$ & $\begin{array}{l}\text { - The layers are much thinner and there is less } \\
\text { material to absorb solar radiation compared to } \\
\text { sc-Si and mc-Si hence, the efficiencies of } \\
\text { thin-film solar modules are lower than } \\
\text { crystalline ones } \\
\text { - Degradation in their power output (in the range } \\
\text { 15-35\%) when exposed to the sun [11] }\end{array}$ \\
\hline $\mathrm{GaAs}$ & $\begin{array}{l}\text { - } 29 \% \text { record efficiency in } \\
\text { laboratory [15] } \\
\text { - The band gap is } 1.43 \mathrm{eV}\end{array}$ & $\begin{array}{l}\text { High efficiency and less thickness than } \\
\text { silicon ones }\end{array}$ & High cost \\
\hline CdTe & $\begin{array}{ll}\text { - } & 10-15 \% \\
\text { - } & (21 \% \text { record efficiency) } \\
& {[15]} \\
\text { - } & \text { The band gap is } 1.45 \mathrm{eV}\end{array}$ & $\begin{array}{l}\text { CdTe cells can exploit a broader } \\
\text { wavelength spectrum than Si cells, close } \\
\text { to the natural one. Low costs, as } \\
\text { cadmium is abundant and generated as } \\
\text { a by-product of important industrial } \\
\text { materials like zinc }\end{array}$ & $\begin{array}{l}\text { Cadmium by itself is one of the most toxic materials } \\
\text { known, and cadmium telluride has some toxic } \\
\text { properties }\end{array}$ \\
\hline CIGS & $\begin{array}{ll}- & 20 \% \\
\text { - } & \text { (under } \\
& \text { certain conditions) } \\
\text { - } & \text { The band gap is } 1.68 \mathrm{eV}\end{array}$ & $\begin{array}{l}\text { - Process is less energy intensive } \\
\text { than manufacturing of the } \\
\text { crystalline silicon solar cell } \\
\text { - Good resistance to heat }\end{array}$ & $\begin{array}{l}\text { - } \quad \text { Less efficient than Si solar cells } \\
\text { - } \quad \text { CIGS cells use toxic chemicals } \\
\quad \text { Currently very expensive to produce }\end{array}$ \\
\hline CIS & $10-13 \%$ & $\begin{array}{l}\text { Processes are less energy intensive } \\
\text { than manufacturing of } \\
\text { crystalline technology } \\
\text { - Good resistance to heat compared } \\
\text { to silicon based modules [16] }\end{array}$ & Relatively expensive due to the materials used \\
\hline $\begin{array}{l}\text { Hybrid (combination } \\
\text { of a-Si and c-Si) [17] }\end{array}$ & Around $21 \%$ & $\begin{array}{l}\text { - Good compromise between cost } \\
\text { and efficiency } \\
\text { - High carrier mobility of } \\
\text { the semiconductor }\end{array}$ & \\
\hline
\end{tabular}

Table 3. Third generation PV cells.

\section{Third Generation Solar Cells}

3rd generation solar panels include several innovative technologies and most of them are still in the research or development phase. Some cells generate electricity by using organic, semi-organic or inorganic materials, hybrid systems, or new technology processes based on nanometer and molecular-scale components. These solar modules are made, in most cases, by thin film type cells.

\begin{tabular}{|c|c|c|c|}
\hline Type & Efficiency & Advantages & Disadvantages \\
\hline PSC & $19-22 \%$ [15] & $\begin{array}{l}\text { - Good efficiency and possibilities } \\
\text { for improvement } \\
\text { Perovskite is cheaper to produce } \\
\text { than silicon }\end{array}$ & $\begin{array}{l}\text { - Perovskite breaks down quick when } \\
\text { exposed to heat, snow, moisture, etc. } \\
\text { - The presence of lead in perovskite is } \\
\text { largely debated for toxicity concerns }\end{array}$ \\
\hline OPV and polymer solar cells & $4-5 \%$, up to $9 \%[15]$ & $\begin{array}{l}\text { Lightweight, mechanical flexibility, } \\
\text { disposability and large-scale roll-to-roll } \\
\text { production capability }\end{array}$ & $\begin{array}{l}\text { Low efficiency, low durability and } \\
\text { low stability }\end{array}$ \\
\hline DSSC & Around $10 \%$ & $\begin{array}{l}\text { - Flexibility, not pollutant, easily } \\
\text { recyclability. Low cost due to the } \\
\text { simple manufacturing process } \\
\text { DSSC work even in } \\
\text { low-light conditions } \\
\text { - High efficiency also at } \\
\text { high temperatures }\end{array}$ & $\begin{array}{l}\text { The electrolyte can freeze at low } \\
\text { temperatures cutting power } \\
\text { production and causing } \\
\text { physical damage } \\
\text { Electrolyte contains volatile organic } \\
\text { solvents and must be carefully sealed }\end{array}$ \\
\hline QDs & Around $1.9 \%$ & Easy synthesis and preparation & Low efficiency \\
\hline
\end{tabular}




\section{Life Cycle Assessment of PV System}

In this section, the authors collected and examined LCA studies applied to PV-based electricity systems.

The studies are divided for PV generations. All studies are described in order to identify and underline the energy and environmental impacts of the examined technologies, the environmental hotspots and methodological key issues.

The review focused on studies written in English and published from 2008 and onwards. The research was conducted using Science-direct database, using "LCA/Life cycle assessment" and "PV/photovoltaic" as keywords, and complemented by a check of cited documents in all relevant papers or reviews of LCA applied to PV systems [18-25]. An additional screening step was taken using Google Scholar, always using the above keywords. Finally, through the consultation of abstracts and exclusion criteria relating to the reference research area (title of the journal, type of publication etc.), the articles were filtered further. Furthermore, authors excluded articles related to PV systems combined with other production energy technologies, product-integrated PVs and concentrated PV systems. The articles analyzed are 39:11 for the first generation PV, 11 for second generation PV and 17 for the third generation PV. The results of the research are discussed below following a chronological order.

\subsection{Energy and Environmental Impacts of PV Solar Cells}

\subsubsection{First Generation Solar Cells Review}

In the following, different LCA studies applied to the first generation PVs are described, focusing of the methodological assumptions and calculated environmental indicators and results.

Fukurozaki et al. [26] examined a $1.2 \mathrm{~kW}_{\mathrm{p}} \mathrm{sc}-\mathrm{Si}$ PV (efficiency of the cell of $15.3 \%$ ) mounted on a rooftop, in Brazil. The authors considered separately all processes, from metallurgical silicon grade (MG-Si) production to panel fabrication, including transportation, installation, and operation. BOS (including supporting structure, inverter and cabling) was considered too. They excluded the decommissioning stage. The lifetime (LT) of the panel, structure, and cabling was 30 years, while the inverter LT was 15 years. The main results regarded cumulative energy demand (CED), energy pay Back Time (EPBT), Global Warming Potential (GWP) and $\mathrm{CO}_{2}$ emission rate. CED was $1619 \mathrm{MJ} / \mathrm{m}^{2}$ of panel area. The most energy intensive processes were the purification of MG-Si (3133 MJ), the mounting construction (2632 MJ) and the panel assembling (2468 MJ). GWP for the entire PV system life cycle was $843 \mathrm{~kg} \mathrm{CO}_{2 \mathrm{eq}}$; the main hotspots were the panel production phase $\left(159 \mathrm{~kg} \mathrm{CO}_{2 \mathrm{eq}}\right)$ and the construction phase $\left(151 \mathrm{~kg} \mathrm{CO}_{2 \mathrm{eq}}\right)$. The EPBT and $\mathrm{CO}_{2}$ emission rate were calculated for different Brazilian locations, characterized by different latitudes and irradiations (from 1506 to $1935 \mathrm{kWh} / \mathrm{m}^{2} /$ year). The highest EPBT value was about 3.13 years while the lowest was 2.47 years; $\mathrm{CO}_{2}$ emissions rate ranged from $14.54 \mathrm{~kg} / \mathrm{kWh}$ to $18.68 \mathrm{~kg} / \mathrm{kWh}$.

Kim et al. [27] evaluated the environmental performance of sc-Si and mc-Si panels with power conditioning system (PCS) and BOS, in Korea. The system boundaries were defined as pre-manufacturing, manufacturing, use and disposal stages. The authors considered two scenarios for the PV efficiency: a base scenario (efficiency: sc-Si 15.95\%; mc-Si 14.91\%) and a best scenario (efficiency: sc-Si $27.60 \%$; mc-Si $20.40 \%$ ). The results related to GWP in the base scenario showed that sc-Si and mc-Si systems emit $41.8 \mathrm{~g} \mathrm{CO}_{2 \text { eq }}$ and $31.5 \mathrm{~g} \mathrm{CO}_{2 \text { eq }}$, respectively. The best efficiency case could reduce the GWP of the sc-Si and mc-Si systems by $34.3 \%$ and $20 \%$. The major contributors in terms of $\mathrm{CO}_{2 \mathrm{eq}}$ (concerning only silicon module manufacturing phase) were the mc-Si and ingot manufacturing processes, due to the electricity required for the purification of mc-Si and for the crystallization process of the ingot. The EPBT of the sc-Si and mc-Si PV systems in the base efficiency case were 4.65 years and 3.68 years, while in the best efficiency case were 3.11 years and 2.97 years. Authors calculated fossil-fuel consumption and $\mathrm{CO}_{2}$ payback time $\left(\mathrm{CO}_{2} \mathrm{PBT}\right)$. The sc-Si and mc-Si PV systems in the base case consumed $0.56 \mathrm{MJ}$ and $0.44 \mathrm{MJ}$ of fossil fuels per $\mathrm{kWh}$, while in the best case there was a reduction of $33 \%$ and $19.3 \%$, respectively. $\mathrm{CO}_{2} \mathrm{PBT}$ values for the base scenario were 2.53 years (sc-Si) and 1.91 
(mc-Si), while for the best case were 1.66 years and 1.53 years, respectively. A sensitivity analysis regarding GWP was performed with different irradiations $\left(1301.35-1700 \mathrm{kWh} / \mathrm{m}^{2} /\right.$ years); the results showed that the increase of irradiation allowed a GWP reduction of $26 \%$ and $22 \%$ for base case, and a reduction of $22 \%$ and $24 \%$ for best case (for sc-Si and mc-Si, respectively).

Stylos and Koroneos [28] estimated the GHG emissions caused during the life cycle of a large-scale grid connected PV system (PV modules, inverters, batteries, and steel foundation), using a cradle to use approach (from raw material extraction to module fabrication and use). They analyzed four different scenarios of manufacturing a mc-Si panel, with cell efficiency variable from $14 \%$ to $20 \%$. The emissions obtained ranged from 12.28 to $58.81 \mathrm{~g} \mathrm{CO}_{2 \mathrm{eq}} / \mathrm{kWh}_{\mathrm{e}}$. In the end, a comparison with $\mathrm{CO}_{2 \mathrm{eq}}$ emissions of a diesel power station was made, showing that carbon footprints of PV systems were lower than diesel power station in every scenario.

Fu et al. [29] performed a LCA for a PV system with mc-Si modules in China. They calculated EPBT and environmental impacts as GWP, acidification potential (AP), eutrophication potential (EP), ozone layer depletion potential (ODP), photochemical ozone creation potential (POCP), and human toxicity potential (HTP), from materials extraction to cell and module fabrication. The authors did not take into account the end-of-life (EoL), due to a lack of accurate data in China about the disposal phase and BOS. The total primary energy demand (PED) from renewable and non-renewable energy was calculated as $0.517 \mathrm{MJ} / \mathrm{kWh}(48.5 \%$ due to mc-Si production stage), while the worst EPBT was 6 years, considering different areas of China. The mean value was approximately 2 years. As concern environmental impacts, AP was $4.27 \times 10^{-4} \mathrm{~kg} \mathrm{SO}_{2 \mathrm{eq}} / \mathrm{kWh}(73.4 \%$ due to sulfur dioxide caused by electricity consumption) and EP was $4.23 \times 10^{-5} \mathrm{~kg} \mathrm{PO}_{4}{ }^{3-}$ eq $/ \mathrm{kWh}$ (mainly due to emissions of nitrogen oxides and phosphate). The calculated GWP of the PV system was $5.09 \times 10^{-2} \mathrm{~kg} \mathrm{CO}_{2 \mathrm{eq}} / \mathrm{kWh}$; the main contributor to GWP was the carbon dioxide (83.6\%). HTP index was $17.76 \times 10^{-2} \mathrm{~kg} \mathrm{DCB}$ eq $/ \mathrm{kWh}$ (dominated by the emissions on air and freshwater (FW)); ODP was $3.02 \times 10^{-9} \mathrm{~kg} \mathrm{R} 11_{\mathrm{eq}} / \mathrm{kWh}$ (dominated by Halon 1301/1211 and carbon tetrachloride) while POCP was $2.69 \times 10^{-5} \mathrm{~kg} \mathrm{C}_{2} \mathrm{H}_{4 \mathrm{eq}} / \mathrm{kWh}$ (mostly caused by inorganic and organic emissions to air). Comparing the environmental impacts of each process, the authors found that the production of solar grade mc-Si contributed the most, accounting for about $52.4 \%$ of the total impacts. The next were the manufacturing processes of cells and modules, accounting for $20.1 \%$ and $18.6 \%$, respectively. Moreover, a sensitivity analysis was conducted to find out the effects on the energy demand and environmental impacts of different factors (electricity and steam consumption during the production of solar grade mc-Si, glass consumption, and disposal during the process of wafer slicing, electricity consumption during the process of cells, aluminum and glass consumption during the modules assembly). It emerged that a $10 \%$ decrease in electricity consumption during solar grade mc-Si production would lead to a $3.37 \%$ drop in PED, $3.97 \%$ in AP, $3.81 \%$ in EP, $3.56 \%$ in GWP and $3.21 \%$ in POCP; a $10 \%$ reduction of aluminum consumption, during the module assembly phase, would lead to a 7.01\% drop in ODP. A $10 \%$ decrease in glass consumption and disposal during wafer slicing process would lead to a decrease of $2.11 \%$ on HTP while a $10 \%$ decrease in steam consumption would lead to a decrease ranging from $0.46 \%$ (EP) to $1.06 \%$ (AP).

A work by Yang et al. [30] for a mc-Si PV module in China focused on international trade, which played a significant role in the development of the Chinese PV industry, and distinguished domestic and imported raw materials. The authors underlined the importance of international trade because it causes the separation of consumption and production of PV products, which are two important phases with different environmental impacts. They considered three scenarios: scenario 1 (baseline), in which all materials were assumed to be produced in China and international trades were ignored; scenario 2, in which mc-silicon was imported as raw material, and scenario 3, that accounted for the market share of all raw materials from various sources. For a better comparison with other previously reported study, only the manufacturing phase was considered. The following impacts were calculated: $\mathrm{GWP}_{100}$, abiotic depletion potential (ADP), AP, EP, HTP, freshwater aquatic eco-toxicity potential (FAEP), marine aquatic eco-toxicity potential (MAEP), terrestrial eco-toxicity potential (TETP), ODP and POCP. GWP was $2.91 \times 10^{+3} \mathrm{~kg} \mathrm{CO}$ eq for scenario 1 and around $2.22 \times 10^{+3} \mathrm{~kg} \mathrm{CO}_{2 \text { eq }}$ for scenarios 
2 and 3; the difference lie in the fact that imported mc-Si manufacturing requires less energy than local production. Mc-Si production was the GWP "hotspot" of the entire process. However, PV module packaging was also a major contributor to GWP. These processes accounted for $52 \%$ and $29 \%$ of GWP in scenario $1,38 \%$ and $38 \%$ in scenario 2 , and $39 \%$ and $38 \%$ in scenario 3 . Other results of the first scenario are shown in Table 4.

Table 4. Environmental impacts of mc-Si PV in scenario 1 [30].

\begin{tabular}{|c|c|}
\hline Environmental Impacts & Results \\
\hline $\mathrm{ADP}$ & $3.40 \mathrm{~kg} \mathrm{SB}$ eq \\
\hline $\mathrm{AP}$ & $17.6 \mathrm{~kg} \mathrm{SO}_{2 \mathrm{eq}}$ \\
\hline $\mathrm{EP}$ & $1.80 \mathrm{~kg} \mathrm{PO} \mathrm{PO}_{4 \mathrm{eq}}$ \\
\hline HTP & $62.5 \mathrm{~kg} 1.4 \mathrm{DB}_{\mathrm{eq}}$ \\
\hline FAEP & $15.2 \mathrm{~kg} 1.4 \mathrm{DB}_{\mathrm{eq}}$ \\
\hline MAEP & $2.69 \times 10^{+2} \mathrm{~kg} 1.4 \mathrm{DB}_{\mathrm{eq}}$ \\
\hline TEPT & $7.10 \times 10^{-2} \mathrm{~kg} 1.4 \mathrm{DB}_{\mathrm{eq}}$ \\
\hline ODP & $4.51 \times 10^{-4} \mathrm{~kg} \mathrm{CFC}-11_{\mathrm{eq}}$ \\
\hline POCP & $0.61 \mathrm{~kg} \mathrm{C} \mathrm{C}_{2} \mathrm{H}_{4 \mathrm{eq}}$ \\
\hline
\end{tabular}

The manufacturing of PV modules in scenarios 2 and 3 allowed reducing impacts for 8 of 10 factors considered; in particular, scenario 2 was similar but never better than scenario 3. Scenario 1 was a better option for ADP and ODP, but the worst option for all other impacts compared to scenarios 2 and 3. Similar to GWP, the processes of mc-Si production and PV module packaging were the major hotspots for all impacts, except for MAEP and FAEP, in which heavy metals were also significant.

Hong et al. [31] evaluated the life cycle environmental effects associated with PV cell (mc-Si) in China. System boundary was set by using a cradle to gate approach. The method used (IMPACT2002+) considered 15 mid-points impact categories, which are presented in Table 5.

Table 5. Mid-points categories results of mc-Si PV in China (IMPACT2002+) [31].

\begin{tabular}{|c|c|}
\hline Mid-Points Categories & Results \\
\hline GWP & $1.84 \times 10^{+3} \mathrm{~kg} \mathrm{CO}_{2 \mathrm{eq}}$ \\
\hline non-renewable energy & $2.41 \times 10^{+4}$ MJ primary \\
\hline carcinogens (CNG) & $12.45 \mathrm{~kg} \mathrm{C}_{2} \mathrm{H}_{3} \mathrm{Cl}_{\mathrm{eq}}$ \\
\hline non-carcinogens (NCG) & $48.96 \mathrm{~kg} \mathrm{C}_{2} \mathrm{H}_{3} \mathrm{Cl}_{\mathrm{eq}}$ \\
\hline ionizing radiation (IR) & $4.83 \times 10^{+3} \mathrm{~Bq} \mathrm{C}-14_{\mathrm{eq}}$ \\
\hline ODP & $3.22 \times 10^{-5} \mathrm{~kg} \mathrm{CFC}-11_{\mathrm{eq}}$ \\
\hline respiratory inorganics (RI) & $2.09 \mathrm{~kg}$ PM 2.5eq \\
\hline respiratory organics $(\mathrm{RO})$ & $0.51 \mathrm{~kg} \mathrm{C} \mathrm{H}_{4} \mathrm{H}_{4 \mathrm{eq}}$ \\
\hline FAEP & $1.11 \times 10^{+5} \mathrm{~kg}$ TEG water \\
\hline TETP & $1.87 \times 10^{+4} \mathrm{~kg}$ TETP soil \\
\hline terrestrial acidification/nitrification (TA) & $71.92 \mathrm{~kg} \mathrm{SO}$ eq \\
\hline land occupation (LO) & $4.22 \mathrm{~m}^{2}$ org. arable \\
\hline aquatic acidification (AA) & $11.80 \mathrm{~kg} \mathrm{SO}_{2 \mathrm{eq}}$ \\
\hline aquatic eutrophication (AE) & $0.08 \mathrm{~kg} \mathrm{PO}_{4} \mathrm{P}$-lim \\
\hline mineral extraction (Mex) & 104.16 MJ plus \\
\hline
\end{tabular}


The production of mc-Si PV cell had a significant contribution to the impact scores in RI, GWP and non-renewable energy but represented a small role to the impact scores in CNG, NCG, and TETP. The contribution of mc-Si PV cell production in the remaining categories was negligible. The results of a sensitivity analysis showed that more than $25 \%$ of overall environmental burden could be reduced by improving energy efficiency, choosing secondary aluminum for mc-Si production, and reducing mc-Si wafer consumption for PV cell production.

Latunussa et al. [32] analyzed an innovative process for the recycling of silicon PV panel, considering that this phase is generally neglected, and that disposal phase will become a relevant environmental issue in the future. The analysis followed a "gate to gate" approach, considering all the impacts from the delivery of the waste to the recycling plant, up to the sorting of the different recyclable materials and the disposal of residues. The impacts of the recycling process of $1000 \mathrm{~kg}$ of silicon PV waste are shown in Table 6.

All these impacts were calculated excluding the credits derived from the energy recovery. The credits related to this energy recovery were significant (around 30\%) for impact categories as ODP, IR (ecosystems), IR (HH), CC, AE and PM; CED could also be reduced from 3150 MJ to 2780 MJ. The results also highlighted that most of the impacts for the recycling process are due to the transport of the PV waste to the site, the plastic incineration, and the further treatment for the recovery of metals from the bottom ash.

Hou et al. [33] investigated the environmental impacts of grid connected power generation from c-Si PVs. The authors included BOS and the fossil fuel burned in transportation and assembly. The results were expressed in terms of EPBT and GHG. EPBT ranged from 1.6 and 2.3 years while GHG ranged from 60.1 to $87.3 \mathrm{~g} \mathrm{CO}_{2 \mathrm{eq}} / \mathrm{kWh}$; about $84 \%$ or even more of the energy consumption and total GHG emission derived from the PV manufacturing process. Also, authors underlined that an improvement in efficiency (from actual $16-18 \%$ to $22 \%$ or higher in the future) could be obtained for the examined c-Si by applying passivated emitter rear locally-diffused (PERL) or heterojunction with intrinsic thin layer (HIT) cell, and this could lead to a GHG emission of $47.5 \mathrm{~g} \mathrm{CO}_{2 \mathrm{eq}} / \mathrm{kWh}$.

Akinyele et al. [34] evaluated the life cycle impacts of a $1.5 \mathrm{~kW}$ solar PV system. In particular, they examined the life cycle emission rate (LCER), GWP, CED, EPBT, and net energy ratio (NER) of six different locations in Nigeria, one for each of the geo-political zones. The different results were dependent from the different radiations of the zones. LCER ranged from 37.3 to $72.2 \mathrm{~g} \mathrm{CO}_{2} / \mathrm{kWh}$ and CED from 380 to $8700 \mathrm{MJ}_{\mathrm{eq}}$, GWP ranged from 1907 to $5819 \mathrm{~kg} \mathrm{CO}_{2 \mathrm{eq}}$, EPBT from 0.82 to 2.3 years and NER from 7.08 to 30.17 .

Table 6. Impact indices of the recycling process of $1000 \mathrm{~kg}$ of silicon PV [32].

\begin{tabular}{|c|c|}
\hline Impact Indices & Results \\
\hline ADP mineral & $4.36 \times 10^{-3} \mathrm{~kg} \mathrm{SB}$ eq \\
\hline CED & $3.15 \times 10^{+3} \mathrm{MJ}$ \\
\hline FAEP & $3.15 \times 10^{+3} \mathrm{CTUe}$ \\
\hline marine eutrophication (ME) & $1.09 \mathrm{~kg} \mathrm{~N} \mathrm{~N}_{\mathrm{eq}}$ \\
\hline $\mathrm{AE}$ & $5.58 \times 10^{-2} \mathrm{~kg} \mathrm{P}_{\mathrm{eq}}$ \\
\hline terrestrial eutrophication (TE) & $12.1 \mathrm{molc} \mathrm{N}_{\mathrm{eq}}$ \\
\hline $\mathrm{AP}$ & 2.68 molc $\mathrm{H}+\mathrm{eq}$ \\
\hline POCP & $3 \mathrm{~kg} \mathrm{NMVOC}$ eq \\
\hline IR (ecosystems) & $9.42 \times 10^{-5} \mathrm{CTUe}$ \\
\hline IR human health $(\mathrm{HH})$ & $30.5 \mathrm{~kg} \mathrm{U} \mathrm{U}_{235 \mathrm{eq}}$ \\
\hline particulate matter $(\mathrm{PM})$ & $9.81 \times 10^{-2} \mathrm{~kg}$ PM $2.5_{\mathrm{eq}}$ \\
\hline HTP (non-cancer effects) & $1.95 \times 10^{-6} \mathrm{CTUh}$ \\
\hline HTP (cancer effects) & $2.95 \times 10^{-5} \mathrm{CTUh}$ \\
\hline ODP & $3.21 \times 10^{-5} \mathrm{~kg} \mathrm{CFC}-11_{\mathrm{eq}}$ \\
\hline climate change $(\mathrm{CC})$ & $4.46 \times 10^{+2} \mathrm{~kg} \mathrm{CO}_{2 \mathrm{eq}}$ \\
\hline
\end{tabular}


Huang et al. [35] considered the life cycle environmental impacts of an mc-PV system in China, with a particular focus on decommissioning and recycling phases. Recycling phase included the dismantling of the modules and the processes connected to main elements like glass (re-melting of glass), ethylene vinyl acetate (EVA) (thermal treatment of EVA), and the chemical treatment of aluminum, argentum, and silicon. The functional unit (FU) (The functional unit is the element of LCA to which all inputs and outputs of the studied system refer. Therefore, when comparing two different systems, the same functional unit must be used.) was a mc-Si PV module with a capacity of $1 \mathrm{~kW}$, containing five $200 \mathrm{~W}_{\mathrm{p}}$ modules. The authors calculated 14 midpoint environmental impacts, considering the production and recycling phases; they only excluded transportation and use phases from the analysis. The 14 environmental impacts were normalized for each process, and a comparison of two different scenarios (landfill and recycling) was made. Mc-Si production, cell processing, and module assembly were the phases with the highest environmental impacts. Focusing on the EoL, the recycling scenario showed fewer environmental impacts than the landfill scenario: even if dismantling of the modules and the treatment of the main elements in the recycling process had a certain environmental burden, their contribution was still lower than the landfill scenario.

Luo et al. [36] made a comparative LCA of PV electricity generation in Singapore by three different mc-Si PV configurations. The FU was one 60-cell silicon PV module and the system boundary was from the mining of silica to the PV system installation. The indicators for evaluating the environmental impacts were EPBT and GHG emissions. The three different roof-integrated PVs consisted in: (1) an aluminum back surface field (Al-BSF) solar cells with a conventional module structure (i.e., glass/encapsulant/cell/encapsulant/back-sheet), (2) a passivated emitter and rear cell (PERC) device with a conventional module structure and (3) a PERC solar cell with a frameless double-glass module structure (i.e., glass/encapsulant/cell/encapsulant/glass). For the examined scenarios the EPBTs were 1.11, 1.08 and 1.01, respectively, while the GHG emissions were 30.2, 29.2, and $20.9 \mathrm{~g} \mathrm{CO}_{2 \mathrm{eq}} / \mathrm{kWhe}$, respectively.

All main results, key-parameters (panel type, PV system, module size, geographical location, efficiency) and methodological aspect (FU, system boundaries and impacts assessment methods) of the above studies are summarized in Table 7.

\subsubsection{Second Generation Solar Cells Review}

The second generation (or thin film PVs) includes low thickness solar cells manufactured by the deposition of semiconductor layers on solid and low-cost substrates of glass, plastic, or metal. The semiconductor layer can be made with a compound of different materials such cadmium, indium, gallium, tellurium, and copper. These materials are less expensive to manufacture than pure silicon, but geographically concentrated only in some areas and, in some cases, are hard to mine [37].

Mohr et al. [38] studied the environmental effects of the substitution of fossil electricity with solar electricity from PVs installed in Western Europe into the life cycle of two types of PV modules: a thin film GaInP/GaAs tandem module (efficiency $28.5 \%$ ) and a classic mc-Si module (efficiency were $14.4 \%$ ). The study considered two scenarios: scenario 0 , in which the environmental impacts of each module were calculated using electricity generated by fossil fuel (hard and brown coal, industrial and natural gas, oil and peat) and scenario S, based on the assumption that the amount of fossil electricity needed in the life cycle of each modules was replaced with the electricity generated by the corresponding module. The authors found that, for both modules, the impact categories that had greater benefit from the substitution of fossil electricity with PV electricity were ADP, AP, GWP, MAEP and POCP. For the GaInP/GaAs module, the impact scores decrease up to a factor of 4.9 (GWP), while for the mc-Si module the impact scores decreased up to a factor of 2.5 (ADP and GWP). The impact categories connected with toxicity were smaller or negligible, comparing the two scenarios. In fact, there is the overlap of a benefit due to the reduction in the use of fossil fuels and of a negative aspect related to the increase in materials (chromium steel for GaInP/GaAs and aluminum for mc-Si module, in particular) for the production of additional PV modules to generate the necessary electricity. 
Table 7. Summary of key-parameters and methodological aspect of the examined case studies (1st generation).

\begin{tabular}{|c|c|c|c|c|c|c|c|c|c|c|c|c|}
\hline Study & $\begin{array}{l}\text { Panel } \\
\text { Type }\end{array}$ & PV System & Module Size & $\begin{array}{c}\text { Geogr. } \\
\text { Location }\end{array}$ & Effic & iency & FU & $\begin{array}{c}\text { System } \\
\text { Boundaries }\end{array}$ & $\begin{array}{c}\text { LCIA } \\
\text { Methodology }\end{array}$ & \multicolumn{3}{|c|}{ Environmental Indices } \\
\hline Fukurozaki et al. [26] & sc-Si & Roof-mounted & $\begin{array}{l}9.5751 \mathrm{~m}^{2} \\
\text { (framed) }\end{array}$ & Brazil & $\begin{array}{l}15.3 \% \text { (cell) } \\
-14 \% \text { (panel) }\end{array}$ & & $1.2 \mathrm{~kW}_{\mathrm{p}}$ & $\begin{array}{l}\text { Cradle to use } \\
\text { (BOS) }\end{array}$ & $\begin{array}{l}\text { - CML } 2001 \\
\text { - EPBT }\end{array}$ & 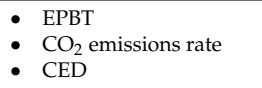 & & \\
\hline Kim et al. [27] & $\begin{array}{l}\text { - } \mathrm{sc}-\mathrm{Si} \\
\mathrm{mc}-\mathrm{Si}\end{array}$ & $\begin{array}{l}\text { Ground } \\
\text { mounted }\end{array}$ & $1,59 \mathrm{~m}^{2}$ & Korea & $\begin{array}{l}\text { Base: } \\
\text { - sc-Si } 15.96 \% \\
\text { mc-Si } \\
14.91 \%\end{array}$ & $\begin{array}{l}\text { Best: } \\
\text { - sc-Si } 27.60 \% \\
\text { mc-Si } \\
20.40 \%\end{array}$ & $1 \mathrm{kWh}$ & $\begin{array}{l}\text { Cradle to grave } \\
\text { (BOS) }\end{array}$ & $\begin{array}{l}\text { - } \mathrm{GWP} \\
\text { - } \mathrm{EPBT}_{2} \mathrm{PBT}\end{array}$ & $\begin{array}{l}\text { - } \mathrm{GWP} \\
\text { - } \mathrm{EPBT}_{2} \mathrm{PBT}\end{array}$ & & \\
\hline Stylos \& Koroneos [28] & mc-Si & & 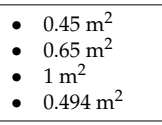 & Greece & $\begin{array}{l}-14 \% \\
-17 \% \\
\end{array}$ & $\begin{array}{l}\text { - } 20 \% \\
-14.1 \% \\
\end{array}$ & $1 \mathrm{kWh}$ & $\begin{array}{l}\text { - Cradle to gate } \\
\text { - Use }\end{array}$ & $\begin{array}{l}\text { Eco- } \\
\text { Indicator ' } 95\end{array}$ & GHG & & \\
\hline Fu et al. [29] & mc-Si & & $1.47 \mathrm{~m}^{2}$ & China & $16 \%$ & & $1 \mathrm{kWh}$ & Cradle to gate & CML2001 & $\begin{array}{ll} & \text { EPBT } \\
: & \text { GWP } \\
: & \mathrm{AP} \\
\mathrm{EP}\end{array}$ & $\begin{array}{ll} & \text { HTP } \\
\text { ODP } \\
: & \text { POCP } \\
\end{array}$ & \\
\hline Yang et al. [30] & $\mathrm{mc}-\mathrm{Si}$ & & Not available & China & & & $1 \mathrm{~kW}_{\mathrm{p}}$ & Cradle to gate & CML 2001 & $\begin{array}{ll}\text { - } & \mathrm{GWP}_{100} \\
& \mathrm{ADP} \\
& \text { - } \\
\text { - } & \mathrm{EP} \\
\text { - } & \mathrm{HTP}\end{array}$ & $\begin{array}{ll} & \text { FAEP } \\
\text { - } & \text { MAEP } \\
\text { - } & \text { TETP } \\
\text { - } & \text { ODP } \\
\text { POCP }\end{array}$ & \\
\hline Hong et al. [31] & $\mathrm{mc}-\mathrm{Si}$ & & Not available & China & $12.7 \%$ & & $1 \mathrm{~kW}_{\mathrm{p}}$ & $\begin{array}{l}\text { Cradle to gate } \\
\text { (BOS) }\end{array}$ & IMPACT2002+ & $\begin{array}{ll}\text { - } & \text { GWP } \\
\text { : } & \text { NCG } \\
\text { - } & \text { RI } \\
\end{array}$ & $\begin{array}{ll} & \text { IR } \\
: & \text { ODP } \\
: & \text { RO } \\
: & \text { FAEP } \\
\text { TETP }\end{array}$ & $\begin{array}{l}\text { TA } \\
\text { : } \mathrm{LO} \\
\text { AA } \\
\text { : } \mathrm{AE} \\
\end{array}$ \\
\hline Latunussa et al. [32] & $\mathrm{c}-\mathrm{Si}$ & & Not available & & & & $\begin{array}{l}1000 \mathrm{~kg} \text { of c-Si } \\
\text { waste panels }\end{array}$ & $\begin{array}{l}\text { Recycling } \\
\text { (Gate to gate) }\end{array}$ & FRELP & $\begin{array}{l}\text { - }{ } \mathrm{AD}_{\min } \\
: \mathrm{CED} \\
: \mathrm{ME} \\
: \mathrm{AE} \\
\cdot \mathrm{TE}\end{array}$ & $\begin{array}{ll}\text { - } & \text { GER } \\
\text { : } & \text { PM } \\
\text { - } & \text { AP }\end{array}$ & $\begin{array}{ll} & \text { POCP } \\
: & \text { ODP } \\
: & \text { CC } \\
: & \text { IR } \\
\text { - FAEP }\end{array}$ \\
\hline Hou et al. [33] & $\mathrm{c}-\mathrm{Si}$ & $\begin{array}{l}\text { LS-PV } \\
\text { Distributed PV }\end{array}$ & $1.12 \mathrm{~m}^{2}$ & China & $17 \%$ & & $1 \mathrm{kWh}$ & $\begin{array}{l}\text { Cradle to use } \\
\text { (BOS) }\end{array}$ & ЕРВТ & $\begin{array}{l}\text { - } \mathrm{EPBT} \\
\text { GHG }\end{array}$ & & \\
\hline Akinyele et al. [34] & $\mathrm{c}-\mathrm{Si}$ & Ground-mounted & $1.63 \mathrm{~m}^{2}$ & Nigeria & $15.4 \%$ & & $1 \mathrm{~kW}_{\mathrm{p}}$ & Cradle to use & $\begin{array}{l}\text { IEC } 61,724 \\
\text { Standard }\end{array}$ & $\begin{array}{l}\text { - GWP } \\
\text { EPBT } \\
\text { - } \text { LCER }\end{array}$ & & \\
\hline Huang et al. [35] & $\mathrm{mc}-\mathrm{Si}$ & & $1.47 \mathrm{~m}^{2}$ & China & $16 \%$ & & $1 \mathrm{~kW}$ & $\begin{array}{l}\text { Cradle to grave } \\
\text { (except } \\
\text { transportation and } \\
\text { use) }\end{array}$ & ReCiPe & $\begin{array}{l}\text { - Metal depletion (MD) } \\
\text { - Fossil depletion (FD) }\end{array}$ & $\begin{array}{l}: \text { ODP } \\
: \text { ME } \\
: \text { FAEP } \\
: \text { HTP } \\
: \text { TETP } \\
\text { POCP } \\
\end{array}$ & $\begin{array}{l}\text { - } \mathrm{IR} \\
: \mathrm{EP} \\
: \mathrm{CC} \\
: \mathrm{PM} \\
\text { - TA } \\
\end{array}$ \\
\hline Luo et al. [36] & $\mathrm{mc}-\mathrm{Si}$ & $\begin{array}{l}\text { Roof- } \\
\text { integrated }\end{array}$ & Not available & Singapore & $\begin{array}{l}\cdot 15.9 \% \\
: \quad 16.7 \% \\
-16.2 \%\end{array}$ & & $\begin{array}{l}\text { One 60-cell } \\
\text { silicon }\end{array}$ & Cradle to use & ЕРВТ & - EPBT & & \\
\hline
\end{tabular}


Van der Meulen and Alsema [39] focused on novel applications of nano-crystalline silicon (nc-Si) materials combined with a-Si devices. In this case, PV module operated in a grid-connected system and it was installed on a rooftop in Southern Europe. The authors examined the life cycle of a-Si and the environmental effects of adding nc-Si layer (this approach it is called "micromorph" technology); they also considered two different clean-processes ( with $\mathrm{SF}_{6}$ and $\mathrm{NF}_{3}$ ) during the module manufacturing phase and two different efficiency values: micromorph module efficiency was $8.5 \%$, while the best amorphous efficiency was $6.7 \%$. Despite this high efficiency, the use of the new technology resulted in higher material (17-20-times higher) and total energy requirements (45\% higher). GHG emissions for a-Si cells were lower than $40 \mathrm{~g} \mathrm{CO}_{2 \mathrm{eq}} / \mathrm{kWh}$, while they were more than $70 \mathrm{~g} \mathrm{CO}_{2 \mathrm{eq}} / \mathrm{kWh}$ for nc-Si/a-Si cells (micromorph technology). Authors also considered improvement scenarios (most likely, optimistic and Oerlikon Solar process) that included an increase of process yield factor from $70 \%$ to $93 \%$, a reduction of thickness bottom layer (from 2000 to $1300 \mathrm{~nm}$ ). And an improvement in $\mathrm{NF}_{3}$-gas utilization. In all scenarios, a-Si technology showed GHG lower than $30 \mathrm{~g} \mathrm{CO}_{2 \mathrm{eq}} / \mathrm{kWh}$, while for the combination of nc-Si/a-Si cells, GHG emissions were always higher than $40 \mathrm{~g} \mathrm{CO}_{2 \mathrm{eq}} / \mathrm{kWh}$ except for optimistic and Oerlikon process with $\mathrm{SF}_{6}$ clean processing. In conclusion, $\mathrm{GHG}$ emissions for the micromorph technology resulted in a $60-85 \%$ increase for $\mathrm{NF}_{3}$ clean processing and $15-90 \%$ in $\mathrm{SF}_{3}$ clean processing, compared to a-Si technology. In addition, the authors found that the use of $\mathrm{NF}_{3}$ lead to higher GHG emissions in comparison with $\mathrm{SF}_{6}$, in particular when production of $\mathrm{NF}_{3}$ and cleaning process are applied to micromorph technology.

A study of environmental indicators and EPBT of CdTe PV systems was made by Held \& Ilg [40]. They considered a ground-mounted power plant in Europe, with an efficiency of $10.9 \%$. The authors calculated GHG emissions and EPBT index. EPBT was from 0.7 to 1.1 years, while GHG emissions ranged from 19 to $30 \mathrm{~g} \mathrm{CO}_{2 \mathrm{eq}}$, depending on the location site. Through CML2001 method, another five impact indices were evaluated in this study: primary energy from resources (PE), AP, EP, GWP, and POCP. The results are shown in Table 8.

Table 8. Environmental impacts of the ground mounted CdTe power plant [40].

\begin{tabular}{cccc}
\hline Phase & Production Phase & $\begin{array}{c}\text { End of Life } \\
\text { (without Recycling Credits) }\end{array}$ & $\begin{array}{c}\text { Life Cycle } \\
\text { (BOS Included, Transportation and Maintenance Excluded) }\end{array}$ \\
\hline $\mathrm{PE}[\mathrm{MJ}]$ & 750 & 81 & 1270 \\
$\mathrm{AP}\left[\mathrm{kg} \mathrm{SO}_{2 \mathrm{eq}}\right]$ & 0.21 & $9.10 \times 10^{-3}$ & 0.36 \\
$\mathrm{EP}\left[\mathrm{kg} \mathrm{PO}_{4}{ }^{3-} \mathrm{eq}\right]$ & 0.018 & $8.03 \times 10^{-4}$ & 0.029 \\
$\mathrm{GWP}_{100}\left[\mathrm{~kg} \mathrm{CO}_{2 \mathrm{eq}}\right]$ & 45.3 & 6.0 & 86.1 \\
$\mathrm{POCP}\left[\mathrm{kg} \mathrm{C}_{2} \mathrm{H}_{4 \mathrm{eq}}\right]$ & 0.015 & $6.63 \times 10^{-4}$ & 0.032 \\
\hline
\end{tabular}

Kim \& Fthenakis [41] made a comparative LCA about energy payback of two different technologies (multi-junction a-Si and nc-Si/a-Si modules). The authors used a cradle-to-gate approach, considering only the production phase (no recycling or disposal); they adopted an efficiency of $6.3 \%$ for the present, and $8 \%$ for future applications. Nc-Si/a-Si modules required an amount of energy between 750 to $1270 \mathrm{MJ} / \mathrm{m}^{2}$, while triple-junction module required $860 \mathrm{MJ} / \mathrm{m}^{2}$. EPBT (nc-Si and a-Si) was 0.7-0.9 years, while triple junction EPBT was 0.8 years.

Mohr et al. [42] made a LCA study of tandem flexible solar cells composed of a-Si/nc-Si (10\% efficiency). The authors also made a comparison between the a-Si/nc-Si PV system roof-integrated and the roof-mounted mc-Si PV system (14.4\% efficiency), both in the Netherlands with an annual insulation of $1000 \mathrm{kWh} / \mathrm{m}^{2}$. EPBT for a-Si/nc-Si PV system was 2.3 years and 3.4 for mc-Si system, while CED was $1.4 \mathrm{MJ} / \mathrm{kWh}$ for both systems. The authors calculated 18 midpoint indices and assessed endpoint level considering the damage to human health, to ecosystem and to resources depletion. The overall damage scores of the a-Si/nc-Si PV system and the mc-Si PV system were 0.012 and 0.010 Ecopoints/kWh, respectively; CC, HTP, PM formation, and FD contributed to $96 \%$ of the overall damage scores for both PV systems.

Kreiger et al. [43] examined a process to reduce the consumption of silane during the manufacturing of two types of PV: a hydrogenated amorphous silicon (a-Si:H) based PV and a tandem (a-Si:H/ $\mu \mathrm{c}-\mathrm{Si}: \mathrm{H})$ with a thin film technology-based PV. The inventory data were based on US and European input 
data, while the approach used was "cradle to gate". Then, a comparison between recycling and no recycling was made. By using a recycling process, the energy consumption decreased (per kg of silane used) from 1146 to $409 \mathrm{MJ}$ for a-Si:H and to $397 \mathrm{MJ}$ for the tandem module a-Si:H/ $\mu \mathrm{c}-\mathrm{Si}: \mathrm{H}$. The GHG emissions decreased (per $\mathrm{kg}$ raw silane) from $61.3 \mathrm{~kg} \mathrm{CO}_{2}$ to $22 \mathrm{~kg} \mathrm{CO}_{2}$ for a-Si:H and to $21.2 \mathrm{~kg} \mathrm{CO}$ for the tandem module a-Si:H/ $\mu$ c-Si:H.

Regarding the importance of the EoL phase, a LCA study of a new treatment based on mechanical process and recycling system, for TFSC, was performed by Giacchetta et al. [44]. In this study, only the EoL phase of a CdTe module was taken into account. The analysis, based on Impact 2002+ methodology, allowed underlining the advantages of this recycling process that resulted in a reduction of all impacts categories compared with incineration, except for IR and LO. Mainly, advantages were connected to glass (the element mostly used in the realization of the PV module), cadmium telluride, and cadmium sulphide recovery, which contributed positively to the reduction of GWP and the consumption of non-renewable energy.

Collier et al. [45] examined two new promising thin-film technologies: copper zinc tin sulphide (CZTS or $\left.\mathrm{CuZnSnS}_{4}\right)$ and zinc phosphide $\left(\mathrm{Zn}_{3} \mathrm{P}_{2}\right)$. The authors assumed an electricity mix from United States and an efficiency of $10 \%$ for both panels. The approach used was a "cradle to gate" and the life cycle impact assessment (LCIA) method was TRACI 2.1. For all four impacts studied (PED, GWP, FW use and eco-toxicity (Ex)), a comparison between the new thin-film PVs ( $\mathrm{Zn}_{3} \mathrm{P}_{2}$ and CZTS), the "old" thin film PVs (a-Si, CdTe, CIGS), and the c-Si PVs (sc-Si and mc-Si) was made. The results are shown in Table 9.

Table 9. Comparison between new thin films and Si-based technologies [45].

\begin{tabular}{cccccccc}
\hline & Zn $_{\mathbf{3}} \mathbf{P}_{\mathbf{2}}$ & CZTS & CdTe & CIGS & sc-Si & mc-Si & a-Si \\
\hline PED [MJ] & 0.27 & 0.64 & 0.29 & 0.60 & 0.70 & 0.57 & 0.35 \\
GWP [kg CO 2 eq] & $3.0 \times 10^{-2}$ & $3.8 \times 10^{-2}$ & $1.8 \times 10^{-2}$ & $3.6 \times 10^{-2}$ & $3.5 \times 10^{-2}$ & $2.9 \times 10^{-2}$ & $1.9 \times 10^{-2}$ \\
FW use [kg] & $4.3 \times 10^{-2}$ & 0.13 & $4.5 \times 10^{-2}$ & 0.13 & 0.62 & 0.14 & $6.9 \times 10^{-2}$ \\
Ex [CTUeco] & $9.1 \times 10^{-6}$ & $2.0 \times 10^{-5}$ & $8.8 \times 10^{-6}$ & $8.4 \times 10^{-6}$ & $8.9 \times 10^{-4}$ & $3.6 \times 10^{-4}$ & $1.95 \times 10^{-5}$ \\
\hline
\end{tabular}

CdTe and $\mathrm{Zn}_{3} \mathrm{P}_{2}$ had similar impacts and outperformed CIGS and CZTS. The impacts from CdTe were slightly greater than that of $Z_{3} \mathrm{P}_{2}$, except for GWP. When compared with Si-based PV, all the four thin film technologies outperformed sc-Si and mc-Si on impacts as Ex and FW use. CdTe and $\mathrm{Zn}_{3} \mathrm{P}_{2}$ performed better for GWP and PED and had impacts similar to a-Si cell. Regarding the dominance analysis, the manufacturing phase was the biggest contributor for all the technologies.

Bergensen et al. [46] performed a hybrid LCA to compare environmental, $\mathrm{HH}$, and natural resource consequences of electricity generated by CIGS and CdTe technologies, in the United States. The authors developed two life cycle inventories for ground-mounted utility scales and roof-mounted distributed-scales PV systems. It was considered a present efficiency (2010) of 12\% for CIGS and 11.6\% for CdTe and a future improvement (for 2030) to $20.8 \%$ and $19 \%$, respectively. In addition, a reduction of thickness was considered for the future scenario. The results showed that the impact categories were similar for both ground-mounted alternative, except LO (since roof-mounted PV use no land directly). The environmental impacts of U.S. thin-film PV technology was at least 90\% lower than those of the U.S. grid mix in seven of 12 categories (AP, GHG, FD, respiratory effects, photochemical oxidation (POx), Ex and EP). In particular, CdTe and CIGS were estimated to emit 20 and $22 \mathrm{~g}$ of $\mathrm{CO}_{2 \mathrm{eq}} / \mathrm{kWh}$ in the present scenario. Considering future scenario, life cycle GHG emissions from CdTe and CIGS were reduced by $69 \%$ compared to their 2010 estimates, to 6 and $7 \mathrm{~g}$ of $\mathrm{CO}_{2 \mathrm{eq}} / \mathrm{kWh}$, respectively.

Lunardi et al. [47] made a comparative LCA of chalcogenide/Si tandem solar modules and they investigated the environmental performances of CIGS/Si, CZTS/Si and AZTS/Si tandem solar cells, compared with Si solar modules. The efficiency of these modules was $22 \%$ and a complete cradle to grave approach was used. The results are shown in Table 10. Si and CIGS/Si presented the worst impacts for most of the examined categories. 
Table 10. Environmental impact results for chalcogenide/Si solar modules [47].

\begin{tabular}{cccc}
\hline & AZTS/Si & CZTS/Si & CIGS/Si \\
\hline GWP $\left[\mathrm{g} \mathrm{CO}_{2 \mathrm{eq}}\right]$ & 25 & 27 & 29 \\
\hline EPBT [years] & 1.3 & 1.3 & 1.4 \\
\hline HTP (cancer effect) $[\mathrm{CTUh} / \mathrm{kWh}]$ & $3.4 \times 10^{-11}$ & $4.6 \times 10^{-11}$ & $4.9 \times 10^{-11}$ \\
\hline HTP (non-cancer effect) $[\mathrm{CTUh} / \mathrm{kWh}]$ & $6.9 \times 10^{-10}$ & $8.6 \times 10^{-10}$ & $1 \times 10^{-9}$ \\
\hline $\mathrm{AE}[\mathrm{kg}$ Peq $/ \mathrm{kWh}]$ & $8.8 \times 10^{-7}$ & $1.08 \times 10^{-}$ & $1.8 \times 10^{-}$ \\
\hline $\mathrm{FAEP}[\mathrm{CTUe} / \mathrm{kWh}]$ & 0.059 & 0.081 & 0.095 \\
\hline $\mathrm{ADP}[\mathrm{kg} \mathrm{Sb}$ eq $/ \mathrm{kWh}]$ & $2.0 \times 10^{-8}$ & $2.1 \times 10^{-8}$ & $2.3 \times 10^{-8}$ \\
\hline
\end{tabular}

In a recent study, Rajput et al. [48] evaluated EPBT, energy production factor (EPF) and life cycle conversion factor (LCCE) of a $3.2 \mathrm{~kW}$ CdTe PV system in India. The efficiency of the cell was $11 \%$. Results showed that EPBT was 3.6 years, EPF was 0.27 and LCCE was 0.0018. These results were compared with some of the studies discussed in this chapter [27,40], founding that EPBT was higher than the other cases. Anyway, all studies differed for location, total capacity installed and, only in two cases, the comparison regarded the same technology (CdTe).

All main results, key-parameters (panel type, PV system, module size, geographical location, efficiency), and methodological aspects (FU, system boundaries and impacts assessment methods) of the above studies are summarized in Table 11. 
Table 11. Summary of key-parameters and methodological aspect of the examined case studies (second generation).

\begin{tabular}{|c|c|c|c|c|c|c|c|c|c|c|c|}
\hline Study & Panel Type & PV System & Module Size & $\begin{array}{l}\text { Geographical } \\
\text { Location }\end{array}$ & $\begin{array}{c}\text { Module } \\
\text { Efficiency }\end{array}$ & $\mathrm{FU}$ & $\begin{array}{c}\text { System } \\
\text { Boundaries }\end{array}$ & $\begin{array}{c}\text { LCIA } \\
\text { Methodology }\end{array}$ & \multicolumn{3}{|c|}{ Environmental Indices } \\
\hline Mohr et al. [38] & $\begin{array}{l}\text { - GaInP/GaA tandem } \\
\text { mc-Si }\end{array}$ & $\begin{array}{l}\text { Mounting } \\
\text { system included }\end{array}$ & Not available & $\begin{array}{l}\text { Western } \\
\text { European }\end{array}$ & $\begin{array}{l}-28.5 \% \\
-14.4 \% \\
\end{array}$ & $1 \mathrm{~kW}_{\mathrm{p}}$ & & CML 2001 & $\begin{array}{ll} & \text { ADP } \\
: & \mathrm{AP} \\
: & \mathrm{EP} \\
: & \mathrm{GWP} \\
\end{array}$ & $\begin{array}{l}\text { - } \mathrm{PO}_{\mathrm{x}} \\
\text { : } \mathrm{HT} \\
\text { - } \mathrm{AE} \\
\text { - } \mathrm{TE}\end{array}$ & \\
\hline $\begin{array}{l}\text { van der Meulen \& } \\
\text { Alsema [39] }\end{array}$ & $\begin{array}{l}\mathrm{nc}^{\mathrm{n}-\mathrm{Si}} \\
\mathrm{a}-\mathrm{Si}\end{array}$ & Rooftop mounted & $1.4 \mathrm{~m}^{2}$ & $\begin{array}{l}\text { Southern } \\
\text { Europe }\end{array}$ & $\begin{array}{l}\cdot \quad 6.7 \% \\
: \quad 8 \% \\
\end{array}$ & $1 \mathrm{~m}^{2}$ & & $\begin{array}{l}\text { - } \mathrm{IPCC}_{2001} \\
\text { - } \mathrm{GWP}_{100}\end{array}$ & GHG & & \\
\hline Kim \& Fthenakis [41] & $\begin{array}{l}\text { - Multi-junction a-SiGe } \\
\text { nc-Si/a-Si }\end{array}$ & & Not available & & $\begin{array}{l}\text { - } \quad 6.3 \% \\
\text { Optimistic: } \\
-8 \%\end{array}$ & $1 \mathrm{~m}^{2}$ & Cradle to gate & $\begin{array}{l}\text { EPBT } \\
\text { Energy } \\
\text { required }\end{array}$ & ЕРВТ & & \\
\hline Held \& Ilg [40] & CdTe & Ground mounted & Not available & Europe & $10.9 \%$ & $1 \mathrm{~m}^{2}$ & $\begin{array}{l}\text { - Manufacturing } \\
\text { - Use } \\
\text { - EoL }\end{array}$ & $\begin{array}{l}\text { - CML2001 } \\
\text { - Primary } \\
\text { energy demand } \\
\text { - EPBT }\end{array}$ & $\begin{array}{l}: \text { EPBT } \\
: \text { GHG } \\
: \text { GWP } \\
\text { POCP }\end{array}$ & $\begin{array}{l}\text { : } \mathrm{PE} \\
: \mathrm{AP} \\
\mathrm{EP}^{2}\end{array}$ & \\
\hline Mohr et al. [42] & $\begin{array}{l}\text { Tandem } \\
\text { a-Si/ncSi }\end{array}$ & Roof-integrated & Not available & Netherlands & $10 \%$ & $1 \mathrm{kWh}$ & $\begin{array}{l}\text { - Manufacturing } \\
\text { - Use } \\
\text { (pisposal } \\
\text { transporting and included) }\end{array}$ & ReCiPe & $\begin{aligned} & \text { CC } \\
& \text { ODP } \\
& \text { HTP } \\
& \text { PM } \\
& \text { IR } \\
& \text { FW } \\
& \text {. MD } \\
&: \text { damage to HH } \\
& \text { damage to eco } \\
&: \text { damage due to } \\
& \text { EPBT }\end{aligned}$ & $\begin{array}{l}\text { LO } \\
\text { Iand } \\
\text { latural } \\
\text { transformation } \\
\text { (NLT) } \\
-\quad \text { FD } \\
\text { systems } \\
\text { o resource depletion } \\
-\quad \text { CD } \\
\end{array}$ & $\begin{array}{ll} & : \text { AE } \\
: & \text { ME } \\
: & \text { TETP } \\
: & \text { FAEP } \\
: & \text { MAEP } \\
: & \text { TA } \\
& \text { POCP } \\
& \\
& \\
\end{array}$ \\
\hline Kreiger et al. [43] & 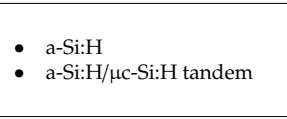 & & Not available & $\begin{array}{l}\text { Input data from } \\
\text { US and } \\
\text { European }\end{array}$ & & $1 \mathrm{~kg}$ of silane & $\begin{array}{l}\text { Cradle-to-gate } \\
\text { Comparison } \\
\text { between recycling } \\
\text { and no recycling }\end{array}$ & $\begin{array}{l}\text { - IPCC } 2007 \\
\text { - GWP } 100 \\
\text { Energy } \\
\text { consumption }\end{array}$ & - $\mathrm{GWP}_{100}$ & & \\
\hline Giacchetta et al. [44] & CdTe & & Not available & & & $1 \mathrm{~m}^{2}$ & EoL & $\begin{array}{l}\text { - Impact } \\
2002+\end{array}$ & - CED & & \\
\hline Collier et al. [45] & 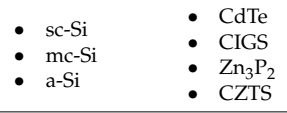 & & Not available & United States & $10.0 \%$ & $1 \mathrm{kWh}$ & Cradle to gate & TRACI 2.1 & - $\mathrm{PED}$ & & \\
\hline Bergesen et al. [46] & $\begin{array}{l}\text { - CIGS } \\
\text { - CdTe }\end{array}$ & $\begin{array}{l}\cdot \text { Ground } \\
\text { mounted } \\
\text { - Roof-mounted }\end{array}$ & Not available & United States & $\begin{array}{l}(2010 \rightarrow 2030) \\
: 12 \% \rightarrow 20.8 \% \\
\cdot 11.6 \% \rightarrow \\
19 \%\end{array}$ & $1 \mathrm{kWh}$ & $\begin{array}{l}\text { - Manufacturing } \\
\text { (BOS) } \\
\text { - Use } \\
\text { - Disposal }\end{array}$ & $\begin{array}{l}\text { - TRACI } 1.0 \\
\text { - ReCiPe }\end{array}$ & $\begin{array}{ll} & \text { Emissions (CO } \\
: & \mathrm{MD} \\
: & \mathrm{LO} \\
& \mathrm{CNG} \\
& \mathrm{FW} \\
\end{array}$ & $\begin{array}{l}\text { 2eq//kWh) } \\
: \text { NCG } \\
: \text { EP } \\
: \text { Ex } \\
\text { POx } \\
\end{array}$ & $\begin{array}{ll} & \mathrm{RE} \\
: & \mathrm{FD} \\
\mathrm{CD}^{\mathrm{CC}} & \mathrm{AP} \\
\end{array}$ \\
\hline Lunardi et al. [47] & Chalcogenide/Si tandem & & Not available & & $22 \%$ & $1 \mathrm{kWh}$ & Cradle to grave & & $\begin{array}{ll}\text { : } & \text { EPBT } \\
: & \text { HTPCNG }_{\text {CNG }} \\
\text { HTPNCG }_{\text {NCG }}\end{array}$ & $\begin{array}{l}\text { : GWP } \\
: \text { FAEP } \\
\text { ADP }\end{array}$ & \\
\hline Rajput et al. [48] & CdTe & & $0.72 \mathrm{~m}^{2}$ & India & $11 \%$ & $3.2 \mathrm{~kW}$ & & ЕРВТ & $\begin{array}{l}\text { : } \mathrm{EPBT} \\
\text { EPF } \\
\text { LCCE }\end{array}$ & & \\
\hline
\end{tabular}




\subsubsection{3rd Generation Solar Cells Review}

The third generation PV refers to all the innovative non-silicon based solar cells that have been developed to overcome the dependency on traditional semiconductors for PV electricity generation. Furthermore, these technologies aim to achieve higher efficiency and reduce cost per watt peak, compared to previous generations [49,50]. Since third generation solar devices have proven their PV performances on the laboratory scale, or their functioning at prototype level only, most of the following studies are quite recent. In addition, many of these technologies have not yet reached the right technological maturity (in terms of efficiency and lifetime) for entering the PV market or diffusion on a wide scale.

The first two works analyzed in this section regarded organic solar cell. The first one [51] was based on the LCA of a typical heterojunction organic cell (LT 15 years) on laboratory scale manufacturing. The analysis was quite complex, due to the fact that the authors analyzed every fabrication step in-depth and the life cycle of all different materials used in the various layers. The results were shown for module efficiency of 5\% (efficiency for laboratory cells) and 10\% (expected industrial efficiency in 2020). Calculated EPBT were four and two years, $\mathrm{CO}_{2}$ emission factors were $109.94 \mathrm{~g} \mathrm{CO}_{2 \mathrm{eq}} / \mathrm{kWh}_{\mathrm{e}}$ and $54.92 \mathrm{~g} \mathrm{CO}_{2 \mathrm{eq}} / \mathrm{kWh}_{\mathrm{e}}$, and ERF were 3.75 and 7.49 , respectively, for the two efficiency values. The PE consumption for $1 \mathrm{~m}^{2}$ of this organic solar module (90\% active area) was $2800 \mathrm{MJ}$; more than $70 \%$ referred to direct process energy (in particular the energy for $\mathrm{N}_{2}$ atmosphere maintenance) while $25 \%$ was attributable to embodied energy cell input materials (indium tin oxide (ITO) and nitrogen were the two main hotspots).

In the second study [52] authors studied a single junction organic solar cell, using different active layers and various combinations of typical donor/acceptor materials, focusing in particular on the role of polymer (the donor material) and fullerene (electron acceptor molecule). The results showed that EPBT ranged from 0.3 to 0.7 while PE ranged from 4 to $7 \mathrm{MJ} / \mathrm{W}_{\mathrm{p}}$, depending on the active materials required. BOS was not considered in the calculations and no device degradation was assumed. Degradation factor is an important aspect of OPV studies, so this might cause an increasing of the calculated EPBT. ITO coated/PET showed a relative high embodied energy $\left(63.45 \mathrm{MJ} / \mathrm{m}^{2}\right)$ compared to the other components (aluminum contacts and encapsulation, $0.048 \mathrm{MJ} / \mathrm{m}^{2}$ and $43.5 \mathrm{MJ} / \mathrm{m}^{2}$ respectively), while the embodied energy of fullerenes was strongly variable (from 65 to $495 \mathrm{GJ} / \mathrm{kg}$ depending on the production method and on fullerenes structure). The main difference between fullerene production techniques (pyrolysis and plasma) is attributable to the electricity and inert gas (argon and helium) required for plasma technique. For this reason, the authors suggested the use of this technique in low-cost electricity areas, or where there are limitations connected to the combustion by-products from the pyrolysis technique.

Sengul and Theis [53] evaluated the environmental impacts of QD-PV considering raw materials acquisition, manufacturing, and use phases. The results of this analysis were compared with literature data of different types of PVs (ribbon mc-Si, mc-Si, sc-Si, CdTe, CIS, DSSC) and with other energy sources like coil, oil, lignite, natural gas, diesel, nuclear, wind, and hydropower. The authors calculated for QD-PV an EBPT (1.5 years), GWP (5 $\left.\mathrm{g} \mathrm{CO}_{2 \mathrm{eq}} / \mathrm{kWh}\right)$, and CED $\left(286 \mathrm{kWh}_{\mathrm{eq}} / \mathrm{m}^{2}\right)$. The EBPT of QD-PV was shorter than the other PV types except for CdTe, while it was of the same order of EPBT of coal, natural gas, and nuclear, lower than the EPBT of lignite and higher than the EPBT of wind and hydropower. Regarding the GWP, considering an estimated efficiency of $14 \%$, QD-PV modules had lower GWP than all PV types, coil, oil, lignite, natural gas and diesel, but higher than nuclear, wind and hydropower energy sources. In addition, QD-PV showed the lowest $\mathrm{SO}_{\mathrm{x}}(\approx 25 \mathrm{mg} \mathrm{SO} / \mathrm{kWh})$ and $\mathrm{NO}_{\mathrm{x}}$ emissions $(\approx 12 \mathrm{mg} \mathrm{NO} / \mathrm{kWh}$ ), with the exception of nuclear, wind, and hydropower, while heavy metal emissions were the highest compared to all other types of PV modules, and the lowest compared to the others energy sources. The main contributors to the energy requirement of QD-PV modules (including PV frame and BOS) were the encapsulation and protection of solar cells (42\%), as well as the production of QD solar cells (33\%) and BOS (21\%). At last, hazardous waste disposal, ITO and 
aluminum foil production were the processes that highly contributed to heavy metal emissions for QD cells production.

Espinosa et al. [54,55], in two different works, made an LCA of flexible polymer solar cells prepared using the roll-to-roll method. Both assessments were based on a cradle to gate approach and the same functional unit ( $1 \mathrm{~m}^{2}$ of processed surface). In the first work [54], the analysis regarded a full roll-to-roll process for the fabrication of flexible polymer solar cell modules. Authors considered an organic solar module efficiency of $2 \%$ and $3 \%$. Results were expressed in terms of EPBT that was 2.02 and 1.35 years, respectively; $\mathrm{CO}_{2}$ emissions were $56.65 \mathrm{~g} \mathrm{CO}_{2 \mathrm{eq}} / \mathrm{kWh}_{\mathrm{e}}$ and $37.77 \mathrm{~g} \mathrm{CO}_{2 \mathrm{eq}} / \mathrm{kWh}_{\mathrm{e}}$, while embodied $\mathrm{CO}_{2}$ was $15.49 \mathrm{~kg} \mathrm{CO}$ eq. The PE consumption of $1 \mathrm{~m}^{2}$ of processed surface (active area $67 \%$ ) was $379 \mathrm{MJ}$, distributed to direct process energy (77 MJ) and embodied energy of input materials (302 MJ); the main contributor to this value was ITO on PET substrate (87\%). The authors also showed how EPBT and ERF changed with efficiency (from $1.25 \%$ to $10 \%$ ) and active area (50\%, 67\%, 85\%). When efficiency was increased from 1.25 to 10, EPBT decreased from 4.34 to 0.54 years (active area $50 \%$ ), from 3.24 to 0.4 years (active area $67 \%$ ), and from 2.55 to 0.32 years (active area $85 \%$ ). In the same way, ERF increased from 3.36 to 27.66 (active area 50\%), from 4.63 to 37.07 (active area 67\%), and from 5.88 to 47.03 (active area $85 \%$ ). The EPBT of the organic cell produced with this roll-to-roll process was in line with the EPBT of dye sensitized modules (0.74-2.1 years, $10 \%$ efficiency) but higher than flexible OPV (0.19 years, 5\% efficiency). In the second work [55], the authors analyzed a new process allowing for the replacement of the ITO electrode in organic modules. The main problem of ITO electrode is indium, a material that could represent a point of congestion for the future of OPV large-scale production. Recycling and EoL scenarios were excluded due to a lack of data, while BOS was not considered. The results showed an EPBT of 9.45 years (1\% efficiency; active area $36.7 \%$ ) but through efficiency optimization it was evaluated that EPBT could fall to 0.94 years $(10 \%$ efficiency and $36.7 \%$ active area). Total equivalent PE consumption per FU ( $1 \mathrm{~m}^{2}$ of processed surface) was 486 $\mathrm{MJ}$, where only $55.6 \mathrm{MJ}$ was due to direct process energy (silver electrode printed and drying during deposition were the main hotspot); the embedded energy in materials was ten times higher than direct process energy (430.37 MJ). Again, authors showed how EPBT and ERF changed with two parameters (efficiency and active area): when efficiency changed from 1\% to 10\%, ERF increased from 1.59 to 15.88 (active area $36.7 \%$ ), from 2.94 to 28.24 (active area $68.1 \%$ ), and from 3.67 to 36.7 ( $85 \%$ active area); EPBT decreased from 5.31 years to 0.53 years (active area $68.1 \%$ ) and from 4.09 years to 0.41 years (active area $85 \%$ ). $\mathrm{CO}_{2 \mathrm{eq}}$ emission factors were $137.68 \mathrm{~g} \mathrm{CO}_{2 \mathrm{eq}} / \mathrm{kWh}_{\mathrm{e}}$ (1\% efficiency), $91.79 \mathrm{~g} \mathrm{CO}_{2 \mathrm{eq}} / \mathrm{kWh}_{\mathrm{e}}(3 \%$ efficiency), and $55.07 \mathrm{~g} \mathrm{CO}_{2 \mathrm{eq}} / \mathrm{kWh}_{\mathrm{e}}\left(5 \%\right.$ efficiency), while embodied $\mathrm{CO}_{2 \mathrm{eq}}$ was $20.66 \mathrm{~kg} \mathrm{CO} 2 \mathrm{eq}$.

Anctil and Fthenakis [56] analysed different processes and material for OPV. The main scope of this LCA was to compare CED of different OPV technologies (single junction small molecule, multi-junction and polymer PV) and to evaluate the impact of using different processing conditions (thermal treatments, interface layers, low bandgap polymer, type of heterojunction). The functional unit chosen was the production of a power of 1 watt-peak $\left(\mathrm{W}_{\mathrm{p}}\right)$. The authors found that fullerenes were the most energy-intensive components of OPV. For this reason, polymer solar cells, that required a high quantity of large fullerenes, had on average a high CED (4.5-5.8 MJ/ $\left.\mathrm{W}_{\mathrm{p}}\right)$ compared to the other OPV technologies. Processes and materials used in small molecule PV had a very low impact on CED, compared to polymer PV. In this case, the other components of the system were a hotspot and CED strictly depended on the efficiency and type of small molecule used (CED was $3.6 \mathrm{MJ} / \mathrm{W}_{\mathrm{p}}$ for $5 \%$ efficiency and $5.9 \mathrm{MJ} / \mathrm{W}_{\mathrm{p}}$ for $3 \%$ efficiency). Regarding multi-junction devices, the greater efficiency $(6.5 \%)$ had no noticeable consequence on the $\mathrm{CED} / \mathrm{W}_{\mathrm{p}}$ that was higher, compared to polymer $\mathrm{PV}$ (5-6.1\% efficiency), and slightly lower than small molecules PV with 3\% efficiency. This result can be explained through the increase of complexity of the devices, as well as the need of additional materials and processes.

Parisi et al. [57] made a comparison of different DSSC configurations, focusing on manufacturing phase. The following configurations (substrate/electrolyte/counter electrode/substrate) were analyzed:

- glass/iquid electrolyte (LE)/ carbon; 
- glass/ionic liquid electrolyte (ILE)/cobalt sulfide (CoS) PET;

- $\quad$ PET/LE/Pt PET; PET/LE/Pt glass;

- $\quad$ steel/LE/Pt PET; steel/LE/Pt glass;

- $\quad$ glass/ILE/Pt glass; glass/LE/Pt glass.

The results showed that the substitution of glass with PET reduced the environmental burden in all impact categories (CC, HTP, LO, NLT, PM, FD); the use of steel (for the solar cell back contact) was a main contributor in most categories, especially FD and CC (HH). The authors also assessed that the replacement of the platinum cathode with a $\mathrm{CoS}$ contributed to lower environmental impacts. Finally, the authors calculated GWP 100 and CED; these indices followed the same trend of previous results. In fact, the configuration with steel-LE-Pt glass was the worst for $\mathrm{GWP}_{100}\left(1.1 \mathrm{~kg} \mathrm{CO}_{2 \mathrm{eq}}\right)$ and CED (43 GJ) while PET-LE-Pt PET had the lowest values (GWP 100 was $0.2-0.3 \mathrm{~kg} \mathrm{CO}_{2 \text { eq }}$ and CED was $10 \mathrm{GJ}$ ).

Azzopardi and Mutale [58] applied LCA to a hybrid QD based solar cell under development. The study was based on laboratory-scale production. Authors compared this solar cell with previous thin film through sustainability criteria results (EPBT, GHG emissions and NER), assuming a 10\% efficiency and a LT of 25 years. They did not consider EoL and recycling due to a lack of data. The calculated EPBT was less than half than crystalline technology (1.51 years). Further, the $\mathrm{CO}_{2 \mathrm{eq}} / \mathrm{kWh}$ was lower (2.89 $\mathrm{g} \mathrm{CO}_{2 \mathrm{eq}} / \mathrm{kWh}$ ). NER was 20.82 for hybrid QD based solar cell (blend type) and 16.66 for hybrid QD based solar cell (variant type). At the end of the work, the authors conducted a sensitivity analysis regarding NER and $\mathrm{CO}_{2 \mathrm{eq}} / \mathrm{kWh}$, varying LT (from 1 to 10 years) and efficiency (from $1 \%$ to $10 \%$ ). The results showed that lifetimes greater than one year and efficiency higher than $1 \%$ are needed for these systems to be less impactful from the energy and environmental points of view.

Espinosa and Krebs [59] assessed the impacts related to an organic tandem solar cell and compared the architecture of this system with a simpler flexible single device. They found that a tandem device performed approximately $20 \%$ better than the single one. The authors considered three different efficiencies (1\%, 3\%, and 5\%) and evaluated an EPBT from 0.24 to 0.3 years and a CED from 43.86 to $51.34 \mathrm{MJ} \mathrm{EPE}_{\mathrm{E}} / \mathrm{m}^{2}$. The mid-point categories calculated with CML2001 method were ADP, AP, EP, $\mathrm{GWP}_{100}$, ODP, TETP, and POx. The environmental hotspots were silver, PET, and electricity. Silver was one of the major drivers of ADP, EP, and TETP, followed by PET and electricity mix. CED for PET and electricity was $16.5 \mathrm{MJ}$ and $14 \mathrm{MJ}$, respectively.

Parisi et al. [60] studied the evolution of the sensitized cells from Gratzel prototype to upscale solar application. The evaluated system was mounted on rooftop and the base efficiency considered was $8 \%$. The performances of the PV system was calculated for different irradiations (corresponding to Nord, Centre and South Europe) with a cradle to gate approach, including the synthesis of main components, fabrication of module, and operational phase. During the study, 17 impact indices and CED index were calculated for three different types of dyes: the porphyrin dye YD2-o-C8, the ruthenium-based dye N719 and the organic metal-free dye D5 dye. The calculated mean values of CED were 224.4 MJ (for YD2-o-C8 dye), 111.2 MJ (for D5 dye) and 61.8 MJ (for N719 dye); the single score indicators were 2.08 points (for YD2-o-C8 dye), 0.81 points (for D5 dye) and 1.07 (for N719 dye). The major impact was due to the module support materials, that could be reduced by about of $35 \%$ changing from glass to polymeric substrate.

A study of a rooftop grid connected DSSC system was conducted by Parisi and Basosi [61]. The main scope of the study was the assessment of NER, GWP ${ }_{100}$, and EPBT indices. The authors used a cradle to gate approach (no recycling phase) and considered an efficiency of $8 \%$. The results showed a NER of 12.67 (considering a LT of 20 years), an EPBT of 1.58 years and a GWP 100 of $22.29 \mathrm{CO}_{2 \mathrm{eq}} / \mathrm{kWh}$. A sensitivity analysis was conducted for all these three parameters. EPBT ranged from 2.11 years to 0.97 years (with efficiency that ranged from $6 \%$ to $13 \%$ ); NER minimum value was 7.30 (efficiency 6\%; LT 15 years), while maximum value was 29.41 (efficiency 13\%; LT 30 years). In the same way, the corresponding values for $\mathrm{GWP}_{100}$ were $38.68 \mathrm{CO}_{2 \mathrm{eq}} / \mathrm{kWh}$ and $9.60 \mathrm{CO}_{2 \mathrm{eq}} / \mathrm{kWh}$. The hotspots for the ten environmental indices (ADP, AP, EP, GWP 100 , ODP, HTP, FAEP, MAEP, TE and POx) were the manufacturing of single cell (from $37 \%$ to $80 \%$ ) and the electricity production ( $20 \%$ to $45 \%$ ). 
Tsang et al. [62] examined the environmental impacts of two different OPV solar modules: a default OPV technology (OPV-D) with polymer-based bulk heterojunction with a fullerene derivative and a polymer in its layer, and a second all-polymer technology (OPV-PP), polymer acceptor-polymer donor. The authors wanted to examine how different production integrations, duration use, and disposal routes influenced the environmental impacts of OPV systems. For this reason, they considered two system scenarios, a solar rooftop array (S1) and a portable solar charger (S2), and two different EoL scenarios, namely landfill and incineration. Then, they compared the results with silicon PV technologies: in particular, OPV (D and PP) with mc-Si in S1 scenario (Table 12) and OPV (D and PP) with a-Si in S2 scenario (Table 13).

Table 12. Comparison between OPV (D and PP) and mc-Si in scenario 1 [62].

\begin{tabular}{cccccc}
\hline Panel Type & \multicolumn{2}{c}{ OPV-D } & \multicolumn{2}{c}{ OPV-PP } & mc-Si \\
\hline & Incineration & Landfill & Incineration & Landfill & \\
\hline $\mathrm{CED}$ & $122 \mathrm{MJ} / \mathrm{m}^{2}$ & $125 \mathrm{MJ} / \mathrm{m}^{2}$ & $108 \mathrm{MJ} / \mathrm{m}^{2}$ & $112 \mathrm{MJ} / \mathrm{m}^{2}$ & $3240 \mathrm{MJ} / \mathrm{m}^{2}$ \\
$\mathrm{EPBT}$ & 436 days & 449 days & 384 days & 398 days & 918 days \\
$\mathrm{CO}_{2}$ PBT & 192 days & 185 days & 175 days & 168 days & 363 days \\
\hline
\end{tabular}

Table 13. Comparison between OPV (D and PP) and a-Si in scenario 2 [62].

\begin{tabular}{cccccc}
\hline Panel Type & \multicolumn{2}{c}{ OPV-PP } & a-Si \\
\hline & Incineration & Landfill & Incineration & Landfill & \\
\hline CED & $293 \mathrm{MJ} / \mathrm{m}^{2}$ & $354 \mathrm{MJ} / \mathrm{m}^{2}$ & $280 \mathrm{MJ} / \mathrm{m}^{2}$ & $341 \mathrm{MJ} / \mathrm{m}^{2}$ & $1100 \mathrm{MJ} / \mathrm{m}^{2}$ \\
EPBT & 220 days & 265 days & 42 days & 45 days & 640 days \\
$\mathrm{CO}_{2}$ PBT & 118 days & 97 days & 16 days & 14 days & 280 days \\
\hline
\end{tabular}

In S1 and S2, for both EoL scenarios, OPV-D and OPV-PP showed better results compared to mc-Si and a-Si results. Finally, a last comparison, concerning relative life cycle impacts, was made between OPV-D (S1 and S2) and m-Si. In S1, OPV-D (incineration) impacts ranged from 97\% lower for TETP to $32 \%$ lower for AE; the only exception was MD that was $21 \%$ higher for OPV-D; in S2, OPV-D impacts ranged from $89 \%$ lower for urban LO to $39 \%$ lower for TETP.

Celik et al. [63] performed a cradle to gate (from laboratory to fab) LCA for different PSC structures suitable for low-cost manufacturing (solution, vacuum and HTL-free). They considered an efficiency of $15 \%$ (best efficiency of $15.6 \%$ ). EPBT for this system was 1-1.5 years, while GWP ranged from 100 to $150 \mathrm{~g} \mathrm{CO}_{2 \mathrm{eq}} / \mathrm{kWh}$. Moreover, nine midpoint environmental impact categories were calculated with TRACI method. The environmental impacts of manufacturing processes are showed in Figure 1 (the values expressed refer to HTL-free process).

For all impact categories, except Ex and ME, the electricity consumption during the manufacturing was a hotspot (50-90\%); in particular, electricity consumption reached a contribution of $80 \%$ for GWP, HTP, PED, and FW use. The results were compared with some first and second generation devices: the total environmental impacts (when all impact categories were normalized to sc-Si ones) of perovskite devices were higher (solution and vacuum) or similar (HTL-free) to mc-Si solar cells, lower than sc-Si solar cells and quite higher than a-Si, CdTe, and CIS solar cells. Regarding electricity requirements, PSC had higher energy requirements than all other technologies. This result was probably influenced by the lack of data on the production of large-scale perovskite cells, and therefore could be subject to change in the future (the same should happen for the corresponding environmental impacts).

The study by Hengevoss et al. [64] described an LCA and eco-efficiency analysis of prospective tandem OPV modules (new materials such as nano-sized zinc oxide, nano-sized silver and semiconductor polymer are used; a light management and a new flexible PET based encapsulation with organic and inorganic barriers). The authors considered a power conversion efficiency of $8 \%$ with LT scenarios of 15 and 20 years. The aim of the LCA was to calculate the environmental impacts 
of this prototype OPV, the EPBT, and GWP for the generated electricity, using two different types of modules (installed on roof top) as benchmark (mc-Si and CdTe). The results for OPV showed that CED was 108-112 MJ eq $/ \mathrm{m}^{2}$, GWP was 5.7-6 $\mathrm{kg} \mathrm{CO} 2 \mathrm{eq} / \mathrm{m}^{2}$, MD was $0.046-0.056 \$ / \mathrm{m}^{2}$ while Ex was 5.3-6.7 CTU $/ \mathrm{m}^{2}$. The OPV module had an EPBT of 1.6 and 2.5 months when exposed to a southern European irradiation value. Finally, considering CED, Ex, MD and EPBT of CdTe and $\mathrm{m}-\mathrm{Si}$, it resulted that $1 \mathrm{~m}^{2}$ of OPV module represented only $3-10 \%$ of $1 \mathrm{~m}^{2}$ of CdTe and mc-Si modules respectively; EPBT of OPV (installed at façade) was $18-55 \%$ of that of the benchmarks and GWP was $12-60 \%$ of that of the benchmarks. One of the most contributors to CED of the OPV was encapsulation $(20 \%)$, followed by the PEDOT:PSS polymer (19\%) and light management (13\%). Including the whole system (module and BOS), the EPBT of OPV added up to 3.4 and 4.7 months. Considering an optimistic efficiency scenario for OPV (10\% power conversion efficiency), GWP decreased by $20 \%$ (15 years LT) and by $19.7 \%$ (20 years LT) for $1000-1200 \mathrm{kWh} / \mathrm{m}^{2} \mathrm{y}$ irradiation, while it decreased by $20 \%$ (15 years LT) and $19 \%$ (20 years LT) for $1800-2000 \mathrm{kWh} / \mathrm{m}^{2} \mathrm{y}$ irradiation.

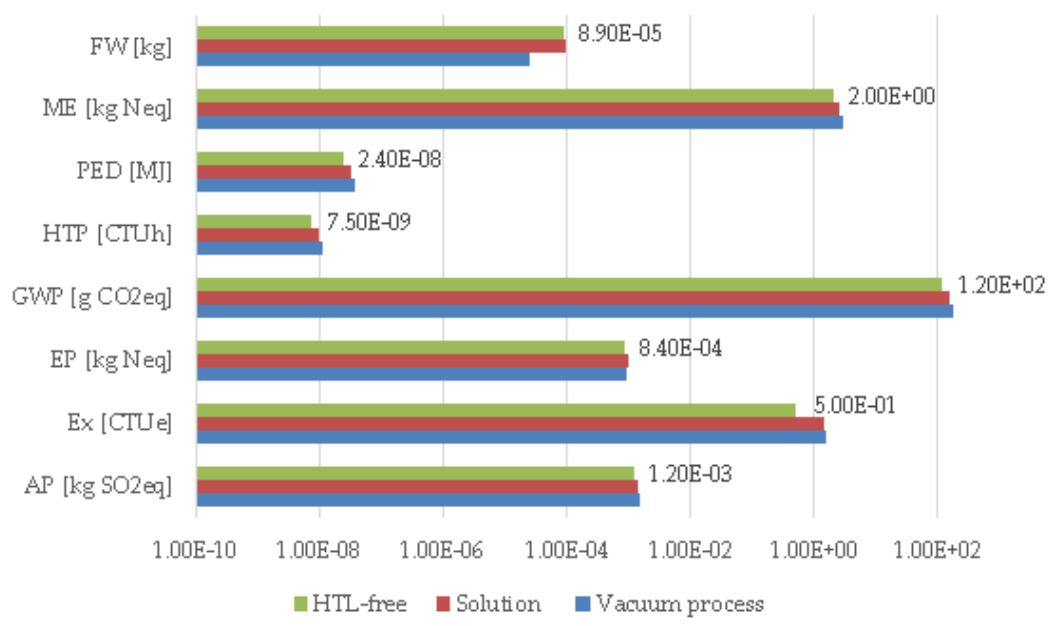

Figure 1. Environmental impacts of manufacturing processes (logarithmic scale 100) [63].

Zhang et al. [65] made a comparison of life cycle environmental impacts of different PSC systems. The study focused on the cradle to grave impacts of five typical perovskite solar cells, developed with different materials and manufacturing processes namely: $\mathrm{MASnI}_{3}, \mathrm{MAPbI}_{3}, \mathrm{FAPbI}_{3}, \mathrm{CsPbBr}_{3}$, and $\mathrm{MAPbI}_{2} \mathrm{Cl}$. The results in terms of primary energy consumption to produce $1 \mathrm{~cm}^{2}$ of active area of solar cells (process energy) and the embodied energy of materials (landfill scenario) are shown in Table 14.

Table 14. Primary energy consumption of perovskite solar cells $\left(1 \mathrm{~cm}^{2}\right.$ active area) and embodied energy of materials (landfill scenario).

\begin{tabular}{cccccc}
\hline Type of Cells & MASnI $_{3}$ & MAPbI $_{3}$ & FAPbI $_{3}$ & $\mathrm{CsPbBr}_{3}$ & MAPbI $_{2} \mathbf{C l}$ \\
\hline PE consumption of $1 \mathrm{~cm}^{2}$ of cell [MJ] & $9.16 \times 10^{-2}$ & $8.06 \times 10^{-2}$ & $8.88 \times 10^{-2}$ & $7.26 \times 10^{-2}$ & $9.12 \times 10^{-2}$ \\
Embodied energy of materials [M]] & 1.5 & 2.01 & 1.96 & 1.28 & 1.49 \\
\hline
\end{tabular}

The $95 \%$ of the embodied energy was from system manufacturing in each solar cell system. The authors selected nine different environmental categories to evaluate the performances of each PSC. Following the previous order ( $\left.\mathrm{MASnI}_{3}, \mathrm{MAPbI}_{3}, \mathrm{FAPbI}_{3}, \mathrm{CsPbBr}_{3}, \mathrm{MAPbI}_{2} \mathrm{Cl}\right): \mathrm{ADP}$ was $1.32 \times 10^{-5}$, $1.28 \times 10^{-5}, 8.11 \times 10^{-6}, 7.13 \times 10^{-6}$, and $8.72 \times 10^{-6} \mathrm{~kg} \mathrm{Sb}$ eq, while GWP was 49.4, 67.2, 63.1, 41.6, and $49.5 \mathrm{~g} \mathrm{CO}_{2 \mathrm{eq}}$. Other results were not expressed in absolute value but only in normalized graphic form; anyway, it emerged that the different environmental impacts obtained may be attributable to the amounts of organic solvents used in the fabrication of the devices and to the different efficiency values. Considering the manufacturing of $1 \mathrm{~cm}^{2}$ of cell as $\mathrm{FU}, \mathrm{MAPbI}_{3}$ and $\mathrm{FAPbI}_{3}$ had the highest impacts, except than ADP; instead, considering the production of $1 \mathrm{kWh}$ as $\mathrm{FU}, \mathrm{MASnI}_{3}$ and $\mathrm{CsPbBr}_{3}$ 
had the highest impacts in all categories. This difference was attributable to the low power conversion efficiency of these cells (only $5.73 \%$ and $4.88 \%$ ) compared to other cells (20\% for $\mathrm{MAPbI}_{3}, 15.56 \%$ for $\mathrm{FAPbI}_{3}, 10.9 \%$ for $\mathrm{MAPbI}_{2} \mathrm{Cl}$ ). The production of $\mathrm{CO}_{2 \text { eq }}$ (GWP) connected with the generation of $1 \mathrm{kWh}(\mathrm{FU})$ of electricity was between 2.63 and $6.78 \mathrm{~kg} \mathrm{CO}_{2 \mathrm{eq}}$, following an inverse trend than that of the efficiency of each cell. In addition, gold production made the largest impact contribution to PV systems, so the substitution of this material (with silver or aluminum) could reduce the total environmental impact score.

Lunardi et al. [66] studied different perovskite/silicon (Si) tandem structure and compared them with three different single junctions PSC (Ag-Au-Al as back electrodes), a sc-Si and a HIT Si cells. They carried out a LCA to evaluate GWP, HTP, AE, FAEP, ADP impacts and the EPBT associated with the three perovskite tandem cells. The differences between these cells were in the materials and in structures. The first two cells used the same HIT Si solar cell for the bottom subcell and the same perovskite structure for the top sub-cell (efficiency of 20\%). The third tandem structure used a more common lower cost p-n junction silicon solar cell (efficiency of $16 \%$ ). All the following results for tandem PSC/Si were calculated in a scenario (20 years) where perovskite solar layer became opaque after 1-year LT, making it impossible for the bottom Si to generate power. Accordingly, it was hypothesized the substitution of materials for perovskite layer every year. The comparison between the environmental impacts of all cells is presented in Figure 2.
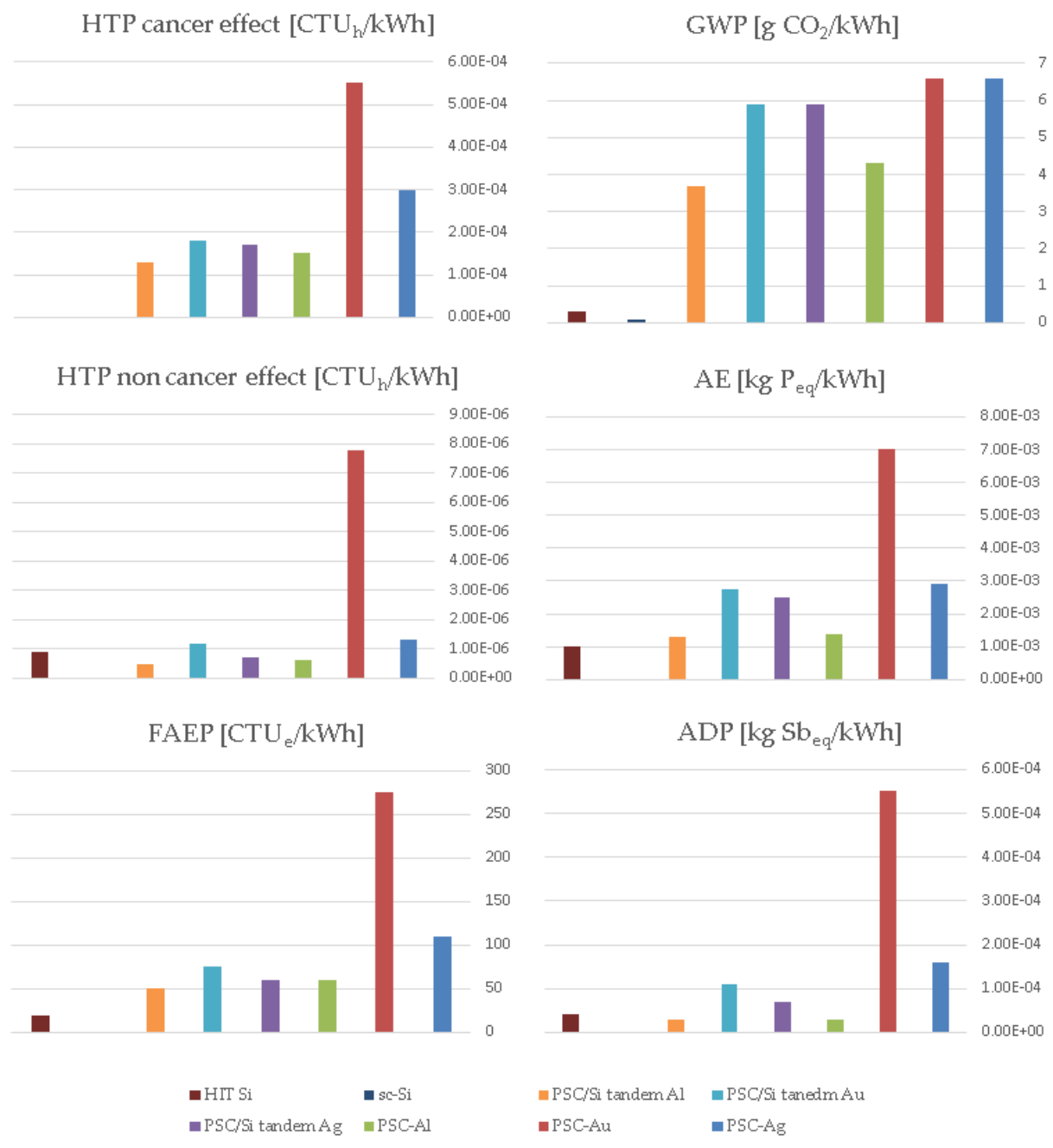

Figure 2. Environmental impacts of different solar cells [66]. 
For a different scenario, the most optimistic for perovskite life, the layer remained electrically conductive after one year and no substitution was required: in this case, all impacts categories related to tandem PSC/Si, except HTP (non-cancer effect), resulted in the same order or lower than that of HIT Si. The EPBT for Si p-n junction was 1.6 years, while for Si HIT was two years. The EPBT for perovskite and perovskite/Si tandem solar cell was lower (1.3-1.5 years), compared to both silicon cells.

Another work about PSC was performed by Maranghi et al. [67]. The authors evaluated the environmental hotspots connected with lab scale fabrication of different PSC configurations, through the harmonization of previous LCA studies of this technology. The PSC configurations analyzed were:

- $\quad \mathrm{FTO}$ glass/TiO $2 / \mathrm{MAPbI}_{3} /$ Spiro-OMeTAD/Au and ITO glass/ZnO/MAPbI $/$ /Spiro-OMeTAD/Ag (G1-G2);

- $\quad \mathrm{FTO}$ glass/ $\mathrm{TiO}_{2} / \mathrm{MAPbI}_{3} /$ Spiro-OMeTAD/Ag (E);

- $\quad \mathrm{FTO}$ glass/ $/ \mathrm{TiO}_{2} / \mathrm{MASnI}_{3} /$ Spiro-OMeTAD/Au (S);

- $\quad \mathrm{FTO}$ glass/TiO $/ \mathrm{T}_{2}$ nanotube (TNT)/ $/ \mathrm{MAPbI}_{3} /$ Iodine $\mathrm{LE} / \mathrm{Pt}$ glass (Z);

- $\quad \mathrm{FTO}$ glass $/ \mathrm{SnO}_{2} / \mathrm{MAPbI}_{3} / \mathrm{CuSCN} / \mathrm{MoOx}-\mathrm{Al}$ solution and vacuum based (C1-C2);

- $\quad \mathrm{FTO}$ glass $/ \mathrm{SnO}_{2} / \mathrm{MAPbI}_{3} / \mathrm{C}-\mathrm{Paste}$ (HTL free) (C3);

- FTO glass $/ \mathrm{TiO}_{2} / \mathrm{MAPbI}_{3}$ (Solvent)/Spiro-OMeTAD/Au with four different solvents (AB1-AB2-AB3-AB4).

Considering $1 \mathrm{~cm}^{2}$ as FU and only the manufacturing phase, which takes place in a European area for all cells, five of the above configurations (S, AB1-4) had higher impacts (results were expressed by points in a single score) compared to the others. Only six of 12 categories showed a percentage impact higher than 1\%: HTP (cancer and no cancer effects), IR, FE, Freshwater Ex, and MD. S configuration had an impact of $22 \mathrm{mPt}$ (milliPoints), while the impact of AB1-AB4 configurations was around $15 \mathrm{mPt}$. For the $\mathrm{S}$ configuration, the hotspot was the gold in the back contact (two orders of magnitude higher than other configurations) while for AB1-AB4, the hotspot was the direct emission of metallic zinc on water (HTP and FAEP). Then, a comparison of CED (calculated with CED-single score impact method) was made: $S$ configuration was out of scale compared to the other configurations (CED $104 \mathrm{MJ}$ ); CED for $\mathrm{Z}$ configuration was 2.6 MJ while for E configuration was 1.2 MJ. All remaining configurations showed a CED equal to or less than $1 \mathrm{MJ}$.

All main results, key-parameters (panel type, PV system, module size, geographical location, efficiency), and methodological aspects (functional unit (FU), system boundaries and impacts assessment methods) of the above studies are summarized in Table 15.

\subsection{Key Parameters}

Key parameters are all those elements of the analysis that affect and define a study. Their importance lies in the fact that the choice of these parameters influences the results of the analysis, both environmental burdens or benefits and energy indices. For this reason, it is necessary to carry out a critical analysis when evaluating these factors [68,69]. Furthermore, the key parameters allow for more coherent and realistic considerations of different analyses when comparing the results. In the case of PV LCA studies, the key parameters identified during this literature review are:

- The efficiency of module or cell;

- The reference geographical location;

- $\quad$ The PV system (BOS);

- The type of panel. 
Table 15. Summary of key-parameters and methodological aspect of the examined case studies (third generation).

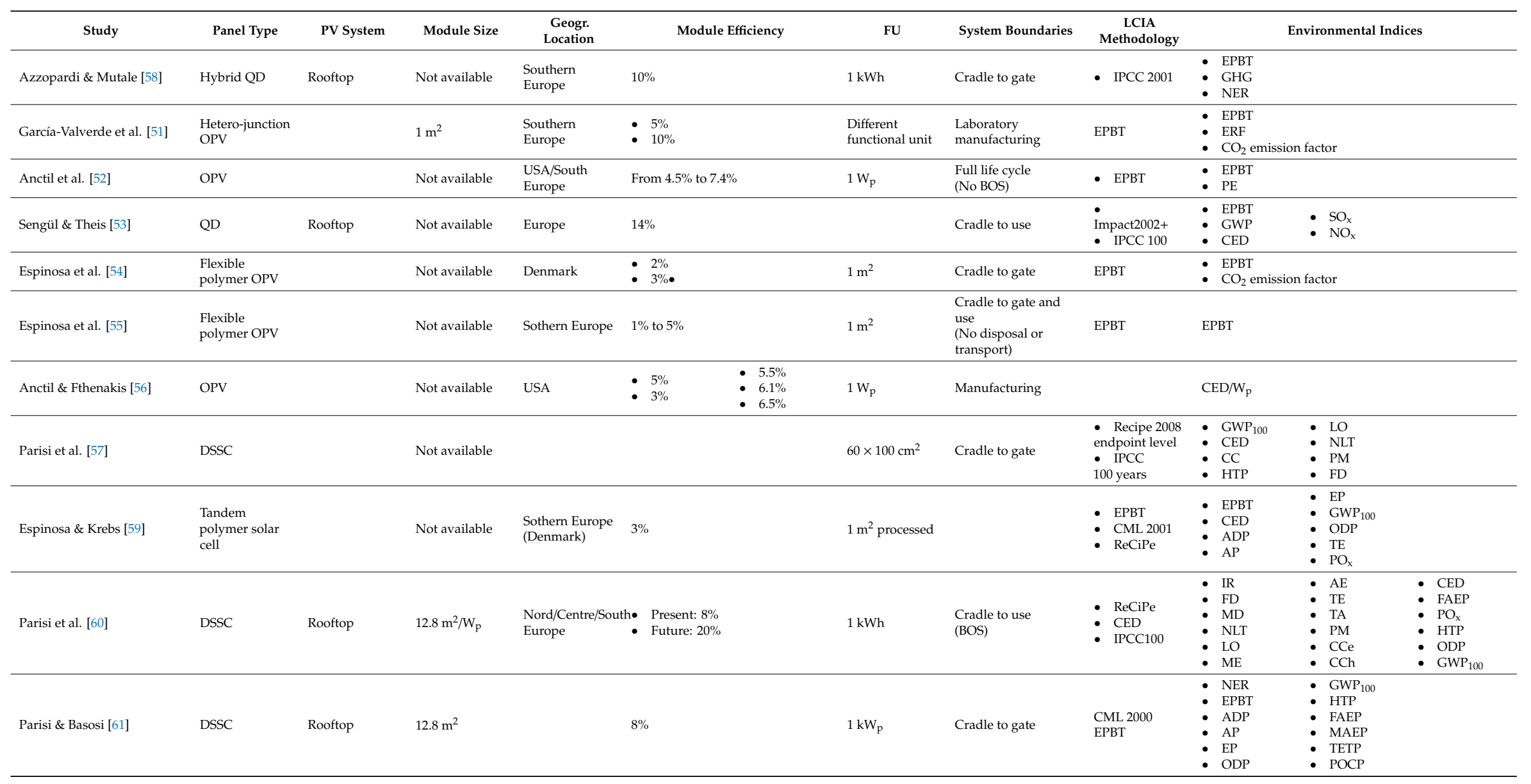


Table 15. Cont.

\begin{tabular}{|c|c|c|c|c|c|c|c|c|c|c|c|}
\hline Study & Panel Type & PV System & Module Size & $\begin{array}{c}\text { Geogr. } \\
\text { Location }\end{array}$ & Module Efficiency & $\mathrm{FU}$ & System Boundaries & $\begin{array}{c}\text { LCIA } \\
\text { Methodology }\end{array}$ & & nvironmental I & \\
\hline Tsang et al. [62] & OPV & $\begin{array}{l}\text { : Rooftop } \\
\text { chartable } \\
\text { chere }\end{array}$ & $75 \mathrm{~cm}^{2} / \mathrm{Wp}$ & Europe & $5 \%$ & $\begin{array}{l}\text { Average } \mathrm{kWh} \\
\text { of electricity } \\
\text { generation } \\
\text { over years }\end{array}$ & $\begin{array}{l}\text { Cradle to grave (BOS } \\
\text { included) }\end{array}$ & & $\begin{array}{l}\text { : } \mathrm{EPBT} \\
\text { EPD } \\
\text { : } \mathrm{CD} \\
\text { - } \mathrm{AE} \\
\end{array}$ & $\begin{array}{ll} & \text { HTP } \\
: & \text { IR } \\
: & \text { TA } \\
: & \text { ME } \\
: & \text { MD } \\
& \text { NLT }\end{array}$ & $\begin{array}{ll} & \text { ODP } \\
: & \mathrm{PM} \\
: & \mathrm{PO}_{\mathrm{x}} \\
: & \mathrm{LO} \\
& \mathrm{FW}\end{array}$ \\
\hline Celik et al. [63] & Perovskite & & Not available & $\begin{array}{l}\text { US electricity } \\
\text { mix }\end{array}$ & $\begin{array}{l}\text { Best } \\
15.6 \%\end{array}$ & $1 \mathrm{kWh}$ & Cradle to gate & $\begin{array}{l}\text { ReCiPe } \\
\text { - TRACI }\end{array}$ & $\begin{array}{ll}\text { - } & \text { EPBT } \\
\text { : } & \text { GWP } \\
\text { : } & \text { FED } \\
\end{array}$ & 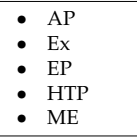 & \\
\hline Hengevoss et al. [64] & $\begin{array}{l}\text { Flexible tandem } \\
\text { OPV }\end{array}$ & Rooftop & Not available & Europe & $\begin{array}{l}: \quad 8 \% \\
-10 \% \\
\end{array}$ & $\begin{array}{l}\text { - } 1 \mathrm{~m}^{2} \\
-1 \mathrm{kWh}\end{array}$ & & EMIS v 5.7 & $\begin{array}{l}\text { - } \text { CED } \\
: \text { EPBT } \\
\text { GWP }\end{array}$ & & \\
\hline Zhang et al. [65] & $\begin{array}{l}\text { Different } \\
\text { perovskite solar } \\
\text { cells }\end{array}$ & & Not available & & $\begin{array}{l}-\mathrm{CsPbBr}_{3}=4.88 \% \\
-\mathrm{MASnI}_{3}-{ }_{\mathrm{x}} \mathrm{Br}_{\mathrm{x}}=5.73 \%\end{array}$ & $\begin{array}{l}: 1 \mathrm{~cm}^{2} \\
-1 \mathrm{kWh}\end{array}$ & Cradle to grave & & $\begin{array}{l}\text { : } \mathrm{ADP} \\
\text { GWP } \\
\text { : } \mathrm{Ex} \\
\text { EP }\end{array}$ & $\begin{array}{l}: \text { HTP } \\
: \text { ODP } \\
: \text { RI } \\
\text { POCP }\end{array}$ & \\
\hline Lunardi et al. [66] & $\begin{array}{l}\text { • } \\
\text { Perovskite/Si } \\
\text { - Si (HIT) } \\
\text { SI (p-n) }\end{array}$ & & & $\begin{array}{l}\text { Southern } \\
\text { Europe }\end{array}$ & $\begin{array}{ll}\text { - } & 24-27 \% \\
\text { - } & 20 \% \\
& 16 \% \\
\end{array}$ & $1 \mathrm{kWh}$ & $\begin{array}{l}\text { Cradle to grave } \\
\text { (All modules go } \\
\text { landfilling) }\end{array}$ & ILCD & $\begin{array}{l}\text { - } \quad \text { EPBT } \\
\text { : } \\
\text { GWP } \\
\end{array}$ & $\begin{array}{ll}\text { - } & \mathrm{HTP}_{\mathrm{CNG}} \\
: & \mathrm{HTP}_{\mathrm{NCG}} \\
\text { : } & \text { FEEP } \\
\end{array}$ & \\
\hline Maranghi et al. [67] & $\begin{array}{l}12 \text { different PSC } \\
\text { configuration }\end{array}$ & & & Europe & & $1 \mathrm{~cm}^{2}$ & Manufacturing & $\begin{array}{l}\text { ILCD } 2011 \\
\text { Midpoint }\end{array}$ & $\begin{array}{ll} & \mathrm{CC} \\
: & \mathrm{ODP} \\
: & { }_{\mathrm{HTP}} \\
: & \mathrm{HTP}_{\mathrm{NCG}} \\
\mathbf{H T M} & \mathrm{PM} \\
\mathbf{1} & \mathrm{MD}\end{array}$ & $\begin{array}{l}: \text { POCP } \\
: \text { AP } \\
: \text { TE } \\
: \text { AE } \\
: \text { ME } \\
: \text { FAEP } \\
\text { LO }\end{array}$ & \\
\hline
\end{tabular}


The importance of key parameters and the way they affect the results are discussed below.

\section{- Efficiency}

In the examined works, authors used different efficiencies to evaluate the results of the analysis, specifying if this parameter is measured (referred to commercial or laboratory scale) or estimated. In some cases, when the solar cells had not reached full maturity in terms of performance and efficiency, the authors considered different future scenarios $[33,41,46,51,54,61,63]$. They hypothesized a performance improvement of the solar panels and calculated the environmental and energy costs arising from an increased efficiency. In other cases, different efficiency scenarios (base/best) were considered, in order to quantify the influence of this parameter on the results.

Generally, the improvements in the conversion efficiency of a PV system resulted in environmental benefits. This led, for example, to a reduction of GWP, $\mathrm{CO}_{2}$ emission factor, $\mathrm{CO}_{2} \mathrm{PBT}$, EPBT, and NER. Varying the efficiency of a certain percentage caused the variation of energy and environmental indices, with the opposite sign. This was certainly verified if the other key parameters, such as the LT of module and annual insolation, were left unchanged. For example, considering Korea grid mix, an improvement of efficiency from $15.96 \%$ to $27 \%$ (for sc-Si and mc-Si) led to a reduction of GWP by $30 \%$ and $20 \%$, respectively [27]. Another example regarded CIGS and CdTe cells: considering a future increase in efficiency from $12 \%$ to $20 \%$ the reduction is expected to be around $28 \%$ for CC, $17 \%$ for CNG and $20 \%$ for MD. Anyway, when the efficiency improvement was obtained through the lowering of the bandgap (to absorb a maximum of photons in one layer) or using a multi-junction approach, the efficiency increased together with the complexity of devices, so additional processing steps and materials were required [56]. It was demonstrated by van der Meulen and Anselma [39] that the transition to a new and efficient technology (in that case from a-Si to micromorph module) does not always allows for a reduction of the environmental impacts. Therefore, it is important that the increase of efficiency significantly to compensate for the extra processing and material requirement, or with no significant changes in module manufacturing. For example, the efficiency of c-Si cells can be changed (from 16-18\% to 20-22\% or higher) by applying PERL/PERC and HIT, and this technology improvement could lead to a reduction of GHG emissions (3.3\% reduction by switching from Al-BSF $\mathrm{m}$-Si cell to PERC and $20-45 \%$ by switching from c-Si to HIT and PERL) thanks to the better power output per Watt $[33,36,66]$.

Therefore, a greater efficiency was equivalent to a greater energy produced and this positively influenced EPBT, ERF and other energy indices [51,54]. Similar considerations can be made taking into account the active area of the module: the improvement of the percentage of active area causes the reduction of EBPT and the increment of EPE and ERF [54,55]. Once again, the problem lies in how the growth of active area is achieved.

\section{- Geographical location: annual insolation and local grid mix}

The reference geographical location has consequences both on the irradiation, which influences the performance of the PV system, and on the energy production mix of the country itself, which affects the environmental impacts considered. Considering the annual insolation, many studies analyzed the performances of the PV panel in different sites of installation, assuming different national geographic conditions. These studies $[27,29,33,34]$ allowed for the assessment of the impact of solar energy potential on the environmental performance of PV systems situated in different locations. Changes in irradiation directly influence the total amount of electricity generated during the life cycle, which is relevant for the energy and environmental impacts and payback time indices of PV systems. For example, Fu et al. [29] showed how AP and EPBT changed for different peak sunshine hours: for PV systems located in first-class areas (1855.6-2100 peak sunshine hours), AP was $2.65 \times 10^{-4}-3.0 \times 10^{-4} \mathrm{~kg} \mathrm{SO}_{2 \mathrm{eq}} / \mathrm{kWh}$ and EPBT was 2.22-2.52 years; in second-class areas (1625-1855.6 peak sunshine hours) AP was $3.0 \times 10^{-4}-3.43 \times 10^{-4} \mathrm{~kg} \mathrm{SO}_{2 \mathrm{eq}} / \mathrm{kWh}$ and EPBT was 2.87-3.36 years, while in fifth-class areas (772.2-1166.7 peak sunshine hours) AP was $4.77 \times 10^{-4}-7.2 \times 10^{-4} \mathrm{~kg} \mathrm{SO}_{2 \mathrm{eq}} / \mathrm{kWh}$ and EPBT was 
4-6.02 years. In this case, for the same PV system, the installation site strongly influenced its environmental impacts. Another example was made by Akinyele et al. [34] that normalized Nigeria's irradiation of six different areas (NE, NW, NC, SE, SW and SS) by conditions of 1700 and $1800 \mathrm{kWh} / \mathrm{m}^{2} /$ year. Since Nigeria is part of the sub-Saharan African region, most of these locations have a high solar irradiation ( $>2200 \mathrm{kWh} / \mathrm{m}^{2} /$ year). The results showed that system operating under the NE, NW, NC, SE and SW zones produced about 31, 27, 16, 5 and $12 \%$ more energy than under the solar irradiation of $1700 \mathrm{kWh} / \mathrm{m}^{2} /$ year, while the system in the SS zone generated $12 \%$ less than under insolation of $1700 \mathrm{kWh} / \mathrm{m}^{2} /$ year. Similarly, the systems in NE, NW, NC and SW produced $24 \%, 20 \%$, $9 \%$, and $6 \%$ more energy than under solar irradiation of $1800 \mathrm{kWh} / \mathrm{m}^{2} /$ year, while the system in the SS zone generates $17 \%$ less.

It emerged that locations with high solar radiation were, obviously, the most suitable for the installation of PV systems, especially if the transportation of PV modules did not contribute much to the total primary energy demand and environmental impacts [29]. Finally, the use of different irradiations helps to understand the influence of this parameter on the performance of the panel and to contextualize the use phase of the device. In addition, it facilitates the comparison with other studies; in fact, this could be an easier way to compare the performances of various panels of different studies, in the same environmental conditions. The geographic location is a key parameter also when the manufacturing of solar devices is examined. The site of production of PV cells is connected with the electricity mix of the reference geographical location and, consequently, this influences the environmental impacts [40]. For example, the impact related to the production of panels in countries that base their electricity mix on non-renewable energy sources is higher than the one related to countries using alternative renewable or nuclear sources. For this reason, in some of the examined studies, the authors estimated some changes on country's mix (increase of electricity production from renewables, reduction in the use of fossil fuels, etc.) to assess how this factor affects the environmental and energy performance of the solar panel $[27,31,33,40]$. For example, Yang et al. [30] reported that a 10\% decrease of coal's share in Chinese energy mix would reduce GWP by $8.93 \%$ while Kim et al. [27] calculated that if $0.45 \%$ of the Korean grid mix was replaced with mc-Si PV systems (conversion efficiency of $20.30 \%$ ) the net $\mathrm{CO}_{2 \mathrm{eq}}$ reduction would be $69.8 \mathrm{MtonCO}_{2 \mathrm{eq}}$.

The geographical position also influences the transport of materials and devices (e.g., transportation of PV modules from the producing area to operating area) [29] and the way in which raw materials are procured (availability of materials, extraction and transport sites, international trades). In fact, the greater the distance between the place of extraction and processing of the raw material, the greater it will be the environmental burden connected to transport to the place of device production. The same applies to the transport from the production place to the place of use. A particular aspect of this regards the international trade of raw materials that cause the separation of environmental impacts among the countries involved in the trade. In this case, the assessment is more complex and only few studies have analyzed these aspects in detail. For example, Yang et al. [30] found that increasing imports of silicon would improve the environmental performance of PV module manufacturing in China. In particular, a 10\% increase in the Chinese market share of imported multi-crystalline silicon would reduce GWP by $1.86 \%$. The reasons for these results can be explained by considering that the manufacturing of $\mathrm{Si}$ is an energy intensive process and China's energy mix is mainly coal-based. They also calculated that 82.4\% of GHG emissions were attributable to the export of PV modules to other countries. This has a beneficial effect on the energy production of the world (zero emissions for use phase) but caused a relevant environmental burden in China.

\section{- $\quad$ The PV system: BOS}

The PV cells are only a part of the whole PV system; in fact, to make a PV installation work properly, accessory elements to compound the modules and structures to support PV modules are essential.

$\mathrm{BOS}$ is the set of electrical equipment like cables, switches, inverters, control and measurement systems, batteries and panel fixing structures. In the analyzed studies, BOS is included or not in the 
assessment. In addition, depending on the specific case, it may be considered as a key element, or not. The impact associated with BOS can be negligible for the first generation PV because the impacts related to the production of the solar cells or modules were generally much higher: according to different studies, the impacts connected to BOS were lower in most of the impact categories. For example, considering GWP and CED [26], BOS had an impact of $46 \mathrm{~kg} \mathrm{CO}_{2 \mathrm{eq}}\left(\approx 5 \%\right.$ of total GWP) and $750 \mathrm{MJ}_{\mathrm{eq}}$ $\left(\approx 5 \%\right.$ of total CED). In the work of Kim et al. [27], GWP due to BOS was $5-7 \%\left(1.35-1.45 \mathrm{~g} \mathrm{CO}_{2 \mathrm{eq}} / \mathrm{kWh}\right)$ of the impact of PV module, and the same happened for the life cycle fossil fuel consumption. However, it is important to point out that, depending on the type of installation and the technology used (rooftop systems, and ground-mounted systems), to neglect the impact of the BOS could lead to underestimate significantly the environmental impacts. For example, if the BOS includes elements like batteries and power conditioning electronics, its impact on the carbon footprint of the PV system can be near 30\% [28]. When considering a PV power plant (CdTe modules), the relative contribution of the BOS on the total impacts can be around 35\% to $45 \%$ [40]. Moreover, BOS seems to have a large impact when associated with second and third generation PV systems [64]. Tsang et al. [62] showed that BOS components such as the mounting structure and inverter had a majority contribution to the impacts in some scenarios: for the scenario including incineration, the BOS contributed from $15 \%$ of the FW use impacts up to $87 \%$ of the agricultural LO. In detail, the BOS accounted for $54 \%$ and $57 \%$ of the CED and CC potential, respectively. In other works, the BOS contributed to nearly half of the energy required for a PV system having hybrid QD-based solar cells [58], and about a third for DSSC [60]. The impact associated with BOS can be reduced significantly by using building-integrated PV systems, alternative materials, and with efficiency improvement: Espinosa and Krebs [59] underlined that, since lightweight and highly flexible OPV designs may be particularly well suited for building integration, BOS impact could be reduced significantly compared with other conventional PV technologies.

- PV typologies: materials used and recycled, manufacturing processes and lifetime

Many key elements are connected to the type of PV technology analyzed and, in particular, to the different materials used/recycled, and to the processes involved in the manufacturing of the cell/module. The differences here may relate to the use of different materials for the layers [52,60], different solar cells architectures [36], different layers deposition times and temperatures [41], different process times, and production processes $[33,39,47]$. Some studies have focused on different manufacturing processes for the same type of module $[28,35,53,67]$.

For the 1st generation PV, the main hotspot for most environmental indices was the silicon production, in particular the manufacturing of mc-silicon, the crystallization of the ingot for sc-Si (that required the maintenance of high temperature) or the metallurgical silicon process into purified silicon (MG-Si) [27]. In fact, all these processes are energy intensive and electricity is one the major contributor to most categories (AP, EP, GWP, and POCP) especially when produced in countries with a coal-based energy mix. Solar grade Si manufacturing contribution was generally more than $40 \%$ in most impact categories (GWP, AP, EP, HTP, POCP), followed by the manufacturing of module and cell (both contributing for $\approx 20 \%$ ). The only exception was ODP index, in which the manufacturing of modules is higher [29], and FAEP and MAEP, in which the hotspot was the cell production [30,33]. Environment impacts not directly related to energy consumption can be attributed to materials such as aluminum and steel, for support and frame [26].

For second generation, absorber materials seem to have a minor role on environmental burdens compared to first generation. In fact, all these technologies generally require a low number of thickness layers and consequently few materials. Further, the transition from raw material to absorber material is less energy intensive compared to silicon treatment. In anay case, electricity consumption during the manufacturing stage (film and contact deposition) had an important role, as well as the encapsulation step and materials $[41,42,45]$. In some cases, the improvement in efficiency of second generation devices can be achieved through the addition of new layers. However, this entails the use of additional materials, a greater consumption of F-gas, such as $\mathrm{SF}_{6}$ and $\mathrm{NF}_{3}$, which causes a greenhouse effect of 
several orders greater than that of $\mathrm{CO}_{2}$ [39], and greater deposition times [41]. Referring to efficiency and deposition times, Kim and Fthenakis [41] estimated that a future $10 \%$ efficiency and a deposition rate of $2-3 \mathrm{~nm} / \mathrm{s}$ could lead to an EPBT reduction of 30\% (around 0.5 years or less) for multi-junction a-Si PV modules with a nc-Si bottom layer. Considering different layers, Lunardi et al. [66] showed how tandem Si-based technologies such as CIGS/Si and CZTS/Si had worse impacts than $\mathrm{Si}(\mathrm{p}-\mathrm{n})$ and $\mathrm{Si}$ (HIT) in most categories (GWP, HTP, FAEP, ADP). However, a high efficiency (30\%) together with the replacing of CdS buffer layer with a non-toxic and more transparent material such AZTS, would lead to overturn these results (except ADP, which would remain more elevated than that of Si $(p-n)$ and $\mathrm{Si}(\mathrm{HIT})$. Again, the increase in efficiency obtained must compensate for the extra materials and energy demand while deposition processes should be faster than the current ones before the full commercialization of these devices.

Focusing on third generation PV materials, most studies were characterized by a certain grade of uncertainty, because processes were made at the laboratory-scale, so it was difficult to predict how the transition to commercial production could influence the results. Probably, the commercial production may reduce the environmental burdens because laboratory production tends to be less efficient than commercial one. Referring to the specific technology, the environmental impacts of OPV technology seems strictly linked to fullerenes and fullerenes derivatives, especially for new generation devices. Indeed, fullerenes used as acceptor were the most energy-intensive components of organic-PV. The embodied energy of these materials ranged from 35 to $123 \mathrm{GJ} / \mathrm{kg}$ while the embodied energy of alternative acceptors such polymers and small molecules ranged from 1.96 to $5.85 \mathrm{GJ} / \mathrm{kg}$ and from 1.17 to $1.85 \mathrm{GJ} / \mathrm{kg}$, respectively. In addition, ITO coated PVs demonstrated high embodied energy [51,52,54], followed by the encapsulation of solar cells. LCA studies of QD based solar cells showed that these devices, compared to thin film, required very small amount of chemical compounds and this contributed to low environmental impacts, but the energy consumption for QD production was greater than the other absorbing material (semiconductor). This disadvantage was compensated by the small quantities of QD used in a PV cell, so they overall had less contribution, to certain parameters, such as CED (45\%), compared to multi-crystalline (77\%), single-crystalline (82\%) and CIS solar cells $(93 \%)$. Particular attention must be paid to the heavy metal emissions (nickel, mercury, arsenic, cadmium, chromium, lead) of these devices, which were the highest compared to other PV technologies (ribbon-Si, sc-Si, mc-Si, CdTe). The processes that contributed the most to heavy metal emissions were hazardous waste disposal, aluminum foil, 1-butanol, ITO, methanol and electricity production [53]. DSSC technology resulted to have an embedded energy value, for laboratory cell production, much lower than the average value calculated for c-Si technologies and of the same order of magnitude of TFSCs. The manufacturing of DSSC was a hotspot (more than $50 \%$ contribution) for all impact categories (ADP, AP, EP, GWP 100 , ODP, HTP, FAEP, MAEP, TETP, POCP), followed by electricity ( $30 \%$ contribution) [60]. For possible configurations and materials, the substitution of glass with PET showed benefits in all impact categories, while the use of steel was still a problem, especially in fossil depletion and CC (HH) categories, such as the use of platinum [60]. Regarding PSCs, the harmonization conducted by Maranghi et al. [67] showed that materials had an important role on environmental categories (mainly HTP and FAEP) and CED. In particular, the use of gold (and other metals as silver and $\mathrm{Pt}$ ) as back contact was the main hotspot, followed by conductive solar glass and electrolyte (mainly $\mathrm{TiO}_{2}$ and TNT). Considering the different perovskite solar cells manufacturing processes, the back contact deposition, the electrolyte deposition and glass substrate preparation had the highest environmental impacts. Again, electricity consumption for the manufacturing process had a great impact on results, but the authors underlined that there is a good margin of improvement in the prevision of large-scale production, also considering that the research concerning this technology is progressing very rapidly.

The recycling phase also plays an important role on LCA of PV system and, for this reason, some works were dedicated to this phase $[27,43,44]$. The reason lies in the fact that it becomes possible the recovery of precious or rare materials and materials that require a great use of energy for their 
manufacturing. For example, Giacchetta et al. [44] found that the recovery of glass (for CdTe PV modules) led to environmental advantages. This is due to the fact that it is one of the most used and heavy components of PV module (95\% mass of the total) and also the recovery of precious materials (CdTe and cadmium sulphide) involved environmental benefits in different categories: $\mathrm{HH}$, Ecosystem quality, CC, GWP and consumption of non-renewable energy. The credits related to the energy recovery could also reach a 30\% reduction for impact categories as ODP, IR (HH and ecosystem), CC, FAEP and PM while CED reduction could be of $11 \%$.

In general, regarding the 1st generation PV, glass, aluminum frame and EVA were the most recyclable materials, with a percentage of recycling near to $70 \%, 10-18 \%$ and $2-5 \%$, respectively. Also, in second generation PV, glass and aluminum recovery had a major role. This is an important aspect considering that glass and aluminum require a high electricity consumption. In the same way, the recycling of toxic elements (cadmium) as well as scare metals (indium) is very important to reduce the environmental impacts in most categories, especially ADP [66]. It must be underlined that in almost all the studies on the PVs of the third generation, the only EoL scenario considered was the landfill, since there was a lack of specific data and information on the recycling processes connected with new technologies, or the recycling processes were not mature enough. However, in some cases, it was possible to assume that glass and metals were recycled offering reduction of mineral resources consumption; inorganic substances were disposed in landfills, potentially offering energy recovery while the rest of polymers and plastics were incinerated [58,61]. What emerges from all these studies is that recycling can be considered a fundamental step in reducing the life cycle burden, thanks to the recovery of materials (especially metal, glass and semiconductor metal recovery) and to net energy saving, compared to landfill. Future research could examine technology-specific recycling processes and investigate the recovery and releases of materials during the end of life stages of PV modules.

Another key element connected to the type of PV is the LT of the solar panel and the other components of the system. The importance of LT is that this parameter influences life cycle energy output or energy consumption and, consequently, some indices as EPBT and NER. In addition, a longer useful life means that, in general, the replacement of the device will be less frequent [66] and the use of new materials and the costs connected to the recycling will be reduced. LT of Si-based technology is around 25-30 years, while for second and third generation devices, there is no reliable information. However, these devices still suffer from various problems, such as degradation due to temperature, moisture, light, and heat, which limit their duration to a few years [44,51,63-65]. In some of the studies analyzed $[29,32,33]$ the estimated LT of the solar panel was the same (25-30 years), while the LT of the inverter was about half [26]. Instead, some authors, due to the uncertainty concerning the LT of some types of solar cells, used different LTs in the same work (like 10 and 20 years) and demonstrated that longer LT of the systems will be the most effective to obtain a reduction of toxicity scores (in particular, FAEP). In other studies, especially those concerning the third-generation cells, it was also rightly considered a performance degradation over the years [58]. For example, Held and Ilg [40] assumed a LT of 30 years with an annual degradation of $0.5 \% / y e a r$. In some cases, a sensitivity analysis was conducted to evaluate the influence of LT on results. Pasini \& Basosi [61] found NER and GWP considering LT changing from 15 to 30 years: the results showed that shorter LT required a higher efficiency to have a high NER value and a low GWP value (at the same efficiency, the increase of NER with LT was $46 \%$ while the reduction of GWP was $46 \%$ ). According to other studies [34,58,61], solar PV systems NER increased with the increasing LT, while EPBT and $\mathrm{CO}_{2 \mathrm{eq}} / \mathrm{kWh}$ decreased. Since PV installations do not release emissions during operational LT, the higher the operational LT of the system (that also means more produced energy during life cycle) the better the environmental profile would be. For these reasons, this parameter needs special attention, now and in future applications, because it can dramatically mitigate energy resources and raw materials exploitation $[28,66]$. 


\subsection{Methodological Insights}

Methodological insights regard all the aspects of the analysis that characterize in detail the LCA study. These aspects are directly linked to the results of the study and, above all, to the choices made by the analyst in order to achieve the scope of the analysis. These features are the system boundaries, the FU, the inventory data (i.e., primary and secondary data), the software used to conduct the assessment, the environmental impact categories and methods [70], etc. Since every analyst is free to make their own choice, and there are multitudes of factors or approaches that affect the LCA studies applied to PV cells, a direct comparison among different studies is often quite difficult. For this reason, Fthenakis et al. [71] developed the "Methodology Guidelines on Life-Cycle Assessment of Photovoltaic Electricity" within the International Energy Agency (IEA) photovoltaic power systems programme. The IEA guidelines represent a useful scheme to direct authors in the choices related to the key parameters of the analysis, to the input of the processes, to the methodological aspects, and to the communication of the results. Focusing on the examined studies, different aspects were identified, as follows:

- The system boundaries;

- The FU;

- The data quality;

- The impact categories and assessment method.

- $\quad$ System boundaries

The system boundary defines which processes are included in the analyzed system and represent the limit between the system and the nature, or the system and other excluded systems. For many examined studies [29-31,41,43,45,54,57,58,61,63] the system boundaries are limited to a "cradle to gate" approach, including raw materials supply and system manufacturing. The use phase is omitted in most of the cases because PV solar panels have zero emissions during this step. In any case, some studies considered a "cradle to use" approach $[26,28,33,34,36,53,55,60]$. The recycling phase is not considered in many works, due to lack of data (especially for the new PV panels, which are the most recent).

Moreover, many studies $[27,35,40,42,46,47,52,62,65,66]$ have analyzed the entire life cycle (from "cradle to grave") while there are few studies $[32,44,51,56]$ focused on the analysis of a single stage (the recycling or the manufacturing phase) of the LCA. The number of works that used the same approach is reported in Figure 3.

- Functional unit

The ISO 14,040 [72] defines the functional unit as the "quantified performance of a product system for use as a reference unit". In other words, FU is the parameter used to link incoming and outgoing flows of the system. Moreover, the FU is the basis on which different alternatives of the same product can be compared.

The studies investigated in this review selected different functional units, as described in the following:

- $\quad \mathrm{kW}_{\mathrm{p}}[26,30,31,33,38,52,56,61]$

- $\quad \mathrm{kWh}[27-29,33,42,45-47,58,60,62,63,66]$;

- $\quad \mathrm{kW}$ capacity $[35,48,64,65]$;

- $\mathrm{m}^{2}[39-41,44,54,55,57,59,64,65,67]$;

- $1000 \mathrm{~kg}$ of Si waste panels [32];

- $1 \mathrm{~kg}$ of silane [43];

- One 60-cell silicon [36]. 


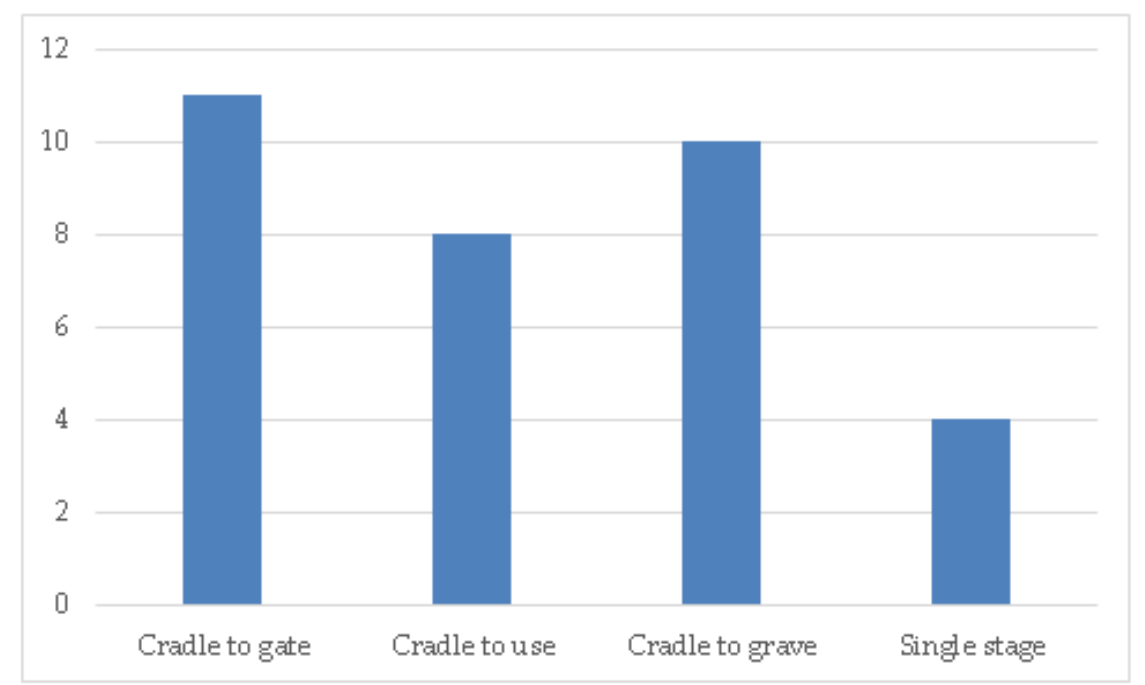

Figure 3. Number of works that used the same system boundaries.

The number of works that used the same FU is reported in Figure 4.

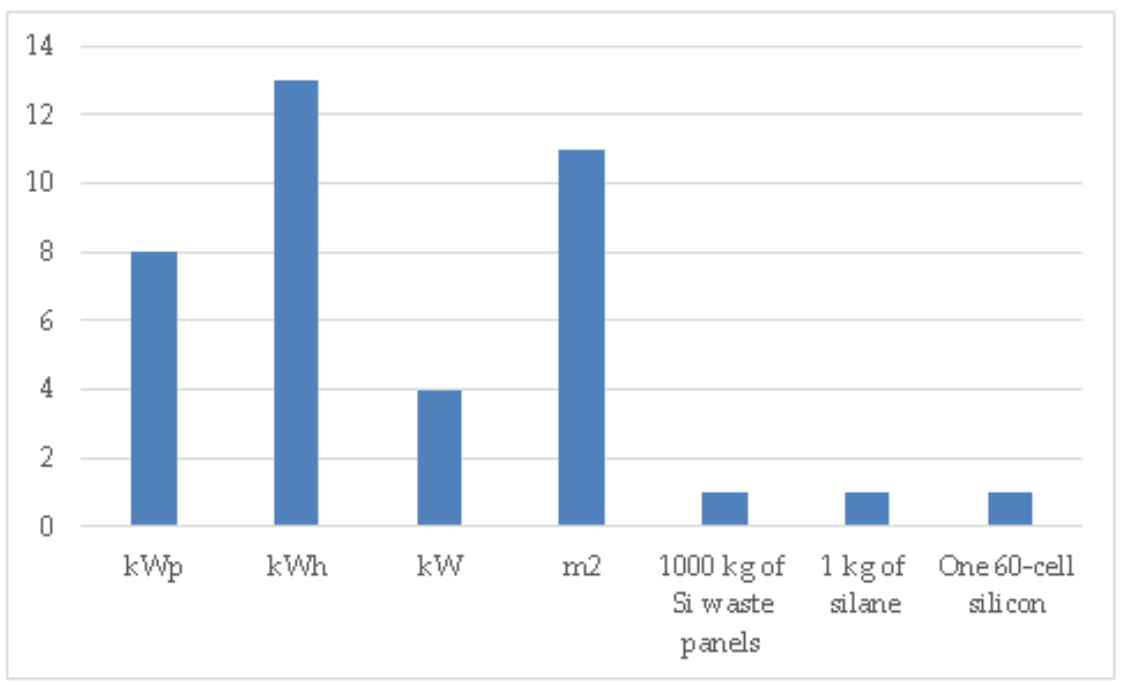

Figure 4. Number of works that used the same FU.

With respect to these FUs, $\mathrm{kWh}$ was the most used for all three generations PV. This is explained by considering that this FU allows for the quantification of the environmental impacts of PV technologies in relation to the final purpose of these devices, namely the production of electricity. $\mathrm{kW}_{\mathrm{p}}$, differently from $\mathrm{kWh}$, it is not ideal to compare the electricity output, since the electricity fed to the grid may differ between different systems analyzed and real operative conditions [71]. The FU $\mathrm{m}^{2}$ is a good option for devices, characterized by different layers or multiple junctions, since it allows estimating the environmental burdens associated with all materials, structure of a PV module (or cell in the case of $\mathrm{cm}^{2}$ ) also considering the supporting structure. It is particularly indicative if used to compare the same technology with different materials in layers or different configurations, since it allows for a direct comparison of a portion of the module with the same base structural characteristics and similar production performances. The other FUs were used only for one or a few studies, depending on the scope and the peculiarity of the analysis. For example, $1 \mathrm{~kg}$ of silane [43] and $1000 \mathrm{~kg}$ of Si waste panels [32] were used because the two analyses focused on environmental impacts connected to the recycling phase. 
- Data quality: primary and secondary data, uncertainty of data

Data used in a LCA study can be classified as primary and secondary data. Primary data are obtained through direct measurements or directly from the specific process or plant; secondary data are through literature studies, publications, LCA libraries and databases.

The analysis of LCA studies of PV panels showed a shortage of primary data on some manufacturing processes, on use phase and a lack of data on recycling phase. This aspect regards in particular the second and third generation solar cells $[38,39,41,45,47,52,59-61,63,65]$. The lack of data for manufacturing processes is justified because second (in most cases) and third generations are still under research and development, in pilot-scale status $[32,56,66]$ or they are not yet in commercial production. Regarding the recycling phase, the lack of data is easily explained for the second and third generation, but it concerns the technologies of the first generation too [28,32]. In fact, the commercial success of first generation devices concerns the last few decades and, as mentioned, these devices have a useful life of 20-30 years. Consequently, information about the EoL phase is not widespread. In these cases, secondary data (from literature and databases) or estimations/assumptions on the EoL of the individual components are often used.

Many studies clearly expressed data information through tables or paragraphs dedicated to this purpose. These data collection information includes:

- typology of data (primary or secondary; foreground or background, etc.);

- data origin or source, if this information is obtained in-situ [64], provided by manufacturing companies or laboratories of new technologies [63] from software database, previous studies or literature [29,40];

- information about temporal and geographical representativeness.

Rarely, an evaluation of data quality was made, as well as an estimation of the influence of missing data substitution $[27,55,60]$.

- Impact categories and assessment methods

Different impact assessment methodologies and impact categories were found in the literature analysis of PV solar systems. Each methodology allows for calculating several impact categories (i.e., GWP, AP, etc.) expressed with specific environmental indicators. Moreover, each method allows for the calculation of environmental indicators based on different assumptions (as regards pollutants and characterization factors) and this can cause uncertainty in the analyses, since all choices can be potentially correct [73].

Some studies focused only on energy assessment through indices as EPBT, CED and NER. Regarding environmental impacts, GHG emissions or GWP are usually calculated for PV panel but also other indicators like AP, EP, OPD, and POCP, etc. In a few cases, categories such as damage to human health, damage to ecosystems, and damage due to resource depletion are evaluated. CED, EPBT, and GWP are the most used indices for PV studies.

The following impact assessment methodologies are used in the various analyses: CML 2000/2001, IMPACT2002+, ReCiPe, Eco-Indicator '95/'99. IPCC, ILCD and TRACI. CML 2001 was the most used methodology for 1st generation PV and, in particular, in China. TRACI method is commonly used in the U.S. while other methods like ReCiPe, Ecoindicator and ILCD were more commonly used in Europe. In some works $[46,57,63]$, authors used a combination of two environmental methods. For example, the TRACI method is used to characterize the potential environmental impacts of emissions for categories such as: $\mathrm{CC}, \mathrm{HH}, \mathrm{Ex}, \mathrm{AP}$, and EP, etc. while the ReCiPe method is used to characterize natural resource consumption for its potential impacts on $\mathrm{MD}, \mathrm{FD}$, water, and land use (since these categories were not included in TRACI). In the same way, when the analysis suggested interesting findings about a particular environmental indicator (for example, if the use of toxic elements emerges, it could be necessary to consider damage to human health category, as well as the use of heavy metal is connected 
to $\mathrm{ME}$ or $\mathrm{FE}$ ), the authors integrated an additional method to evaluate that particular category, if not evaluated previously. In few cases, authors used two different methods to calculate different categories at midpoint and endpoint level. For example, Espinosa and Krebs [59] used CML2001 as a midpoint method and ReCiPe as an endpoint method. In any case, the above differences about the methods used and the fact that, in some cases, results were expressed only in normalized form, make it difficult to compare the results among the studies.

\section{Conclusions}

The aim of this work was to focus on environmental hotspots, key parameters and methodological insights through the analysis of LCA studies of PV systems, from first to third generation.

The literature review showed a fair availability of LCA studies applied to PV solar cells, in particular about third generation technologies. It emerged how the key aspects, such as the efficiency, the geographical location, the type of PV cells, the technology used for manufacturing, the analysis of auxiliary components, the EoL phase (considering materials and parts recycling), together with the different methodological aspects chosen by the LCA analysts, influence the results of the various studies. Moreover, the literature review showed that, even when similar modules are examined, it is difficult to compare different studies, since LCA analysts can choose different methodological approaches when conducting the analysis. In addition, other factors (such as the different configurations of the modules, installations, and efficiencies, etc.) make it even more complicated to compare the results. Anyway, it was possible to determine which are the common hotspots related to environmental indicators, or to a particular process and life cycle phase.

Electricity consumption had great impacts in most categories, and for all generations, so it is important to aim, as far as possible, for less energy-intensive manufacturing processes or to reduce environmental burdens by using an energy mix not based primarily on fossil fuels.

Regarding the first generation $\mathrm{PV}$, the specific contribution to environmental impacts is largely attributable to manufacturing and treatment of mc-Si and sc-Si, which result to be energy intensive processes. For second and third generations, manufacturing processes require less energy than silicon treatment and the environmental impacts are, in most cases, lower compared to the first generation. However, there are still margins of improvement with regard to the production techniques used, in terms of layer deposition times and temperature, encapsulation step, etc. Moreover, many aspects still need to be carefully evaluated, especially for technologies that are not commercially viable yet; for example, the use of materials that have a large embodied energy such as fullerenes and ITO covered (OPV and QD), the use of substances that have particular criticalities regarding the heavy metal emissions to water and soil (QD and perovskite) or the stability of some electrolytes at low temperatures (DSSC). Another non-negligible aspect of emerging PV technologies is connected to the use of precious materials (gold, silver, copper, and platinum) or potentially toxic elements. In this case, although the results of LCA analyses are often better at environmental level compared to mature technologies (e.g., Si based PV), it is important to consider the real sustainability of a scenario of large-scale diffusion of these devices. First of all, the lack of sufficient raw materials and the absence of valid alternatives to maintain or improve the performances, if rare or precious materials are used. Secondly, the need to evaluate in-depth the long-term effects of the release of new materials or toxic elements (such as cadmium) to landfill (if they are not expected to be recovered). Finally, the importance of extending risk scenarios, evaluating the consequences (currently not widely considered) of accident events, which could cause the modules to catch fire, and the possible release of fragments into the environment [74]. Actually, the great challenge concerning new devices is the improvement of efficiency, useful life, and production processes, considering the impact of their potential large-scale commercialization. In fact, as emerged from the sensitivity analyses conducted in various studies, the increase in efficiency is one of the most decisive parameters for assessing the sustainability and the real impacts that next generation solar cells will have in the future. The same goes for the LT parameter, which allows for a reduction in the consumption of materials and the environmental impacts connected to their 
use. Further, it allows for amortizing the energy costs of the life cycle of the devices since they can produce more energy over time. In this context, the research must focus on the analysis of different configurations (evaluating the availability, costs, and quality of the materials used) and on alternative production processes, highlighting which are critical aspects of each technology in relation to the different environmental categories.

For all these reasons previously exposed, the recycling of materials and, in some cases, the energy obtained from the combustion of some elements, allows to amortize the environmental burdens compared to the simple landfill scenario. In any case, it is necessary to evaluate this aspect case by case, and to consider the impact of the transport to the treatment sites and the energy required for the separation of materials sent to recycling, that could grow with the complexity of devices.

A last consideration must be made for EPBT, a recurring index in LCA of PV, which is indicative of the system's sustainability from an energy point of view: the trend that emerges from this review is that EPBT parameter is lower as technology increases; so in general, first generation shows relative high EPBT (more than two years), while third generation EPBT is lower than two years, especially considering the improvement in efficiency, where it often drops even under one year. However, this aspect does not concern $\mathrm{CO}_{2}$ emissions and CED. In these cases, the best technologies seem to be those of the second generation, which ensure a good compromise between efficiency and the maturity of production processes. In this sense, future analyses could provide more indications, when new technologies will reach a greater stability in terms of energy performance and lifetime. In addition, it is expected that the emission factors and the price of the modules will change in the future. An improvement of life cycle environmental performance could be obtained thanks to the improvement of efficiency in the use phase, technological innovations, energy efficiency, and environmental sustainability of the production processes and materials used. Dynamic LCA and consequential LCA studies will be useful for evaluating the change in emission factors and costs. Finally, from this review, it emerges the need to motivate the reasons for the choices made and the importance of the quality and origin of the data used, which are often omitted. Since many studies are based on secondary data taken from previous analyses, this helps to identify the most similar and coherent situations, and leads to less uncertainty with respect to the results. Moreover, it is clearly important that using different environmental assessment methods and the application of sensitivity analysis both allow to evaluate the influence of certain parameters on the results, and further facilitates a comparison among the different studies, which generally differ in various aspects related to the analyst choices, and to the peculiarity of the object of the study.

Author Contributions: All authors have contributed equally to this work. All authors have read and agreed to the published version of the manuscript.

Funding: This research received no external funding.

Conflicts of Interest: The authors declare no conflict of interest.

\section{List of Acronyms}

$\begin{array}{ll}\mu \mathrm{m} & \text { Micrometers } \\ \text { AA } & \text { Aquatic acidification } \\ \text { AC } & \text { Alternating Current } \\ \text { ADP } & \text { Abiotic depletion potential } \\ \text { AE } & \text { Aquatic eutrophication } \\ \text { Al-BSF } & \text { Aluminum Back Surface Field } \\ \text { AP } & \text { Acidification Potential } \\ \text { a-Si } & \text { Amorphous Silicon } \\ \text { a-Si:H } & \text { Hydrogenated Amorphous Silicon } \\ \text { BOS } & \text { Balance of system } \\ \text { CC } & \text { Climate change } \\ \text { CdS } & \text { Cadmium Sulfide }\end{array}$




\begin{tabular}{|c|c|}
\hline CdTe & Cadmium Telluride \\
\hline CED & Cumulative Energy Demand \\
\hline CIGS & Copper Indium Gallium Selenide \\
\hline CIS & Copper Indium Selenide \\
\hline CNG & Carcinogens \\
\hline $\mathrm{CO}_{2} \mathrm{PBT}$ & $\mathrm{CO}_{2}$ payback time \\
\hline $\operatorname{CoS}$ & Cobalt Sulfide \\
\hline c-Si & crystalline silicon \\
\hline $\mathrm{CZ}$ & Czochralski \\
\hline CZTS & Copper Zinc Tin Sulfide \\
\hline $\mathrm{DC}$ & Direct Current \\
\hline DSSC & Dye-Sensitized Solar Cell \\
\hline EoL & End of life \\
\hline EP & Eutrophication Potential \\
\hline EPBT & Energy payback time \\
\hline EPE & Equivalent primary energy \\
\hline $\mathrm{EPF}$ & Energy production factor \\
\hline ERF & Energy return factor \\
\hline EU & European Union \\
\hline EVA & Ethylene Vinyl Acetate \\
\hline Ex & Eco-toxicity \\
\hline FAEP & Freshwater aquatic eco-toxicity \\
\hline FD & Fossil depletion \\
\hline FU & Functional Unit \\
\hline FW & Freshwater \\
\hline GaAs & Gallium Arsenide \\
\hline GHG & Greenhouse gas emissions \\
\hline GWP & Global warming potential \\
\hline $\mathrm{HH}$ & Human Health \\
\hline HIT & Heterojunction with Intrinsic Thin Layer \\
\hline HTP & Human Toxicity Potential \\
\hline ILE & Ionic Liquid Electrolyte \\
\hline IR & Ionizing radiation \\
\hline ITO & Indium Tin Oxide \\
\hline LCA & Life Cycle Assessment \\
\hline LCIA & Life Cycle Impacts Assessment \\
\hline LCCE & Life cycle conversion factor \\
\hline LCER & Life cycle emissions rate \\
\hline LE & Liquid Electrolyte \\
\hline LO & Land occupation \\
\hline LT & Lifetime \\
\hline MAEP & Marine aquatic eco-toxicity potential \\
\hline mc-Si & Multi-Crystalline Silicon \\
\hline MD & Metal depletion \\
\hline ME & Marine eutrophication \\
\hline Mex & Mineral extraction \\
\hline MG-Si & Metallurgical Grade Silicon \\
\hline NCG & Non-carcinogens \\
\hline nc-Si & Nano-Crystalline Silicon \\
\hline NER & Net energy ratio \\
\hline NLT & Natural land transformation \\
\hline $\mathrm{nm}$ & Nanometers \\
\hline ODP & Ozone layer depletion potential \\
\hline OPV & Organic Photovoltaic \\
\hline
\end{tabular}




$\begin{array}{ll}\text { PCS } & \text { Power Conditioning System } \\ \text { PE } & \text { Primary energy } \\ \text { PED } & \text { Primary energy demand } \\ \text { PERC } & \text { Passivated Emitter and Rear Cell } \\ \text { PERL } & \text { Passivated Emitter Rear Locally-diffused } \\ \text { PM } & \text { Particulate matter } \\ \text { POCP } & \text { Photochemical ozone creation potential } \\ \text { POx } & \text { Photochemical oxidation } \\ \text { PSC } & \text { Perovskite Solar Cell } \\ \text { PV } & \text { Photovoltaic } \\ \text { QD } & \text { Quantum Dot } \\ \text { RI } & \text { Respiratory inorganics } \\ \text { RO } & \text { Respiratory organics } \\ \text { SC-Si } & \text { Single-Crystalline Silicon } \\ \text { TA } & \text { Terrestrial acidification } \\ \text { TE } & \text { Terrestrial eutrophication } \\ \text { TETP } & \text { Terrestrial eco-toxicity potential } \\ \text { TFSC } & \text { Thin Film Solar Cell }\end{array}$

\section{References}

1. Schmela, M. Global Market Outlook, For Solar Power/2018-2022; SolarPower Europe: Brussels, Belgium, 2018; Available online: https://www.solarpowereurope.org/wp-content/uploads/2018 (accessed on 3 January 2020).

2. Schmela, M. Global Market Outlook, For Solar Power/2019-2023; SolarPower Europe: Brussels, Belgium, 2019; Available online: https://www.solarpowereurope.org/wp-content/uploads/2019 (accessed on 3 January 2020).

3. Beccali, M.; Cellura, M.; Finocchiaro, P.; Guarino, F.; Longo, S.; Nocke, B. Life Cycle Assessment performance comparison of small solar thermal cooling systems with conventional plants assisted with photovoltaics. Energy Procedia 2012, 30, 893-903. [CrossRef]

4. SETAC. Society of Environmental Toxicology and Chemistry; SETAC: Pensacola, FL, USA, 1993; Available online: https://www.setac.org/page/sciencelca (accessed on 3 January 2020).

5. European Commission. Communication from the Commission to the European Parliament, the Council, the European Economic and Social Committee and the Committee of the Regions: United in Delivering the Energy Union and Climate Action-Setting the Foundations for a Successful Clean Energy Transition; European Commission: Brussels, Belgium, 2019; p. 285.

6. Hagerty, K.; Cormican, J. Components of Your Solar (Photovoltaic) System. Available online: https: //www.altestore.com/ (accessed on 20 June 2019).

7. Askari, M.B. Types of Solar Cells and Application. Am. J. Opt. Photonics 2015, 3, 94. [CrossRef]

8. Shaheen, S.; Ginley, D.; Jabbour, G. Organic-Based Photovoltaics: Toward Low-Cost Power Generation. MRS Bull. 2005, 30, 10-19. [CrossRef]

9. Bagnall, D.M.; Boreland, M. Photovoltaic technologies. Energy Policy 2008, 36, 4390-4396. [CrossRef]

10. IRENA. International Renewable Energy Agency. Renewable Energy Technologies: Cost Analysis Series. Solar Photovoltaics; Volume 1: Power Sector Issue 4/5; IRENA: Abu Dhabi, UAE, 2012; Available online: http: //www.irena.org/Publications (accessed on 3 January 2020).

11. Green, M.A. Third Generation Photovoltaics: Advanced Solar Energy Conversion. Springer Series in Photonics (12); Springer: Berlin/Heidelberg, Germany, 2006. [CrossRef]

12. Aberle, A.G. Fabrication and characterization of crystalline silicon thin-film materials for solar cells. Thin Solid Films 2006, 511, 26-34. [CrossRef]

13. Sørensen, B. Renewable Energy: Physics, Engineering, Environmental Impacts, Economics and Planning, 5th ed.; Academic Press: Cambridge, MA, USA, 2017.

14. Hossam-Eldin, A.; Rafaey, M.; Farghly, A. A Review on Photovoltaic Solar Energy Technology and Its Efficiency. In Proceedings of the Conference: 17th International Middle-East Power System Conference (MEPCON'15), Mansoura, Egypt, 15-17 December 2015; Available online: https://www.researchgate.net/ publication/28779239 (accessed on 3 January 2020). 
15. Green, M.A.; Hishikawa, Y.; Dunlop, E.; Levi, D.; Hohl-Ebinger, J.; Toshita, M.; Ho-Baillie, A.W.Y. Solar cell efficiency tables (version 53). Prog. Photovolt. Res. Appl. 2018, 27. [CrossRef]

16. Gul, M.; Kotak, Y.; Muneer, T. Review on recent trend of solar photovoltaic technology. SAGE J. Energy Explor. Exploit. 2016, 34, 485-526. [CrossRef]

17. Wu, L.; Tian, W.; Jiang, X. Silicon based solar cell system with a hybrid PV module. Sol. Energy Mater. Sol. Cells 2005, 87, 637-645. [CrossRef]

18. Baharwani, V.; Meena, N.; Dubey, A.; Brighu, U.; Mathur, J. Life cycle assessment of solar PV System: A review. Int. J. Environ. Res. Dev. 2014, 4, 183-190.

19. Chatzisideris, M.D.; Espinosa, N.; Laurent, A.; Krebs, F.C. Eco-design perspective of thin film photovoltaic technologies: A review of life cycle assessment studies. Sol. Energy Mater. Sol. Cells 2016, 156, 2-10. [CrossRef]

20. El Chaar, L.; Lamont, L.A.; El Zein, N. Review of photovoltaic technologies. Renew. Sustain. Energy Rev. 2011, 15, 2165-2175. [CrossRef]

21. Gerbinet, S.; Belboom, S.; Léonard, A. Life Cycle Analysis (LCA) of photovoltaic panels: A review. Renew. Sustain. Energy Rev. 2014, 38, 747-753. [CrossRef]

22. Parida, B.; Iniyan, S.; Goic, R. A review of solar photovoltaic technologies. Renew. Sustain. Energy Rev. 2011, 15, 1625-1636. [CrossRef]

23. Peng, J.; Lu, L.; Yang, H. Review on life cycle assessment of energy payback and greenhouse gas emission of solar photovoltaic systems. Renew. Sustain. Energy Rev. 2013, 19, 255-274. [CrossRef]

24. Sherwani, A.F.; Usmani, J.A. Life cycle assessment of solar PV based electricity generation systems: A review. Renew. Sustain. Energy Rev. 2010, 14, 540-544. [CrossRef]

25. Wong, J.H.; Royapoor, M.; Chan, C.W. Review of life cycle analyses and embodied energy requirements of single-crystalline and multi-crystalline silicon photovoltaic systems. Renew. Sustain. Energy Rev. 2016, 58, 608-618. [CrossRef]

26. Fukurozaki, S.H.; Zilles, R.; Sauer, I.L. Energy Payback Time and $\mathrm{CO}_{2}$ Emissions of $1.2 \mathrm{~kW}$ photovoltaic Roof-Top System in Brazil. Int. J. Smart Grid Clear Energy 2012, 164-1699. [CrossRef]

27. Kim, B.J.; Lee, J.Y.; Kim, K.H.; Hur, T. Evaluation of the environmental performance of sc-Si and mc-Si PV systems in Korea. Sol. Energy 2014, 99, 100-114. [CrossRef]

28. Stylos, N.; Koroneos, C. Carbon footprint of polycrystalline photovoltaic systems. J. Clean. Prod. 2014, 64, 639-645. [CrossRef]

29. Fu, Y.; Liu, X.; Yuan, Z. Life-cycle assessment of multi-crystalline photovoltaic (PV) systems in China. J. Clean. Prod. 2015, 86, 180-190. [CrossRef]

30. Yang, D.; Liu, J.; Yang, J.; Ding, N. Life-cycle assessment of China's multi-crystalline silicon photovoltaic modules considering international trade. J. Clean. Prod. 2015, 94, 35-45. [CrossRef]

31. Hong, J.; Chen, W.; Qi, C.; Ye, L.; Xu, C. Life cycle assessment of multi-crystalline silicon photovoltaic cell production in China. Sol. Energy 2016, 133, 283-293. [CrossRef]

32. Latunussa, C.E.L.; Ardente, F.; Blengini, G.A.; Mancini, L. Life Cycle Assessment of an innovative recycling process for crystalline silicon photovoltaic panels. Sol. Energy Mater. Sol. Cells 2016, 156, 101-111. [CrossRef]

33. Hou, G.; Sun, H.; Jiang, Z.; Pan, Z.; Wang, Y.; Zhang, X.; Zhao, Y.; Yao, Q. Life cycle assessment of grid-connected photovoltaic power generation from crystalline silicon solar modules in China. Appl. Energy 2016, 164, 882-890. [CrossRef]

34. Akinyele, D.O.; Rayudu, R.K.; Nair, N.K.C. Life cycle impact assessment of photovoltaic power generation from crystalline silicon-based solar modules in Nigeria. Renew. Energy 2017, 101, 537-549. [CrossRef]

35. Huang, B.; Zhao, J.; Chai, J.; Xue, B.; Zhao, F.; Wang, X. Environmental influence assessment of China's multi-crystalline silicon (multi-Si) photovoltaic modules considering recycling process. Sol. Energy 2017, 143, 132-141. [CrossRef]

36. Luo, W.; Khoo, Y.S.; Kumar, A.; Low, J.S.C.; Li, Y.; Tan, Y.S.; Wang, Y.; Aberle, A.G.; Ramakrishna, S. A comparative life-cycle assessment of photovoltaic electricity generation in Singapore by multicrystalline silicon technologies. Sol. Energy Mater. Sol. Cells 2018, 174, 157-162. [CrossRef]

37. Brook, A.E. Chapter 18-Solar Energy: Photovoltaics. In Future Energy Improved, Sustainable and Clean Options for Our Planet, 2nd ed.; Elsevier Science: London, UK, 2014; pp. 383-404. 
38. Mohr, N.; Meijer, A.; Huijbregts, M.A.J.; Reijnders, L. Environmental impact of thin-film GaInP/GaAs and multicrystalline silicon solar modules produced with solar electricity. Int. J. Life Cycle Assess. 2009, 14, 225-235. [CrossRef]

39. van der Meulen, R.; Anselma, E. Life-cycle greenhouse gas effects of introducing nano-crystalline materials in thin-film silicon solar cells. Prog. Photovolt. Res. Appl. 2010, 19, 453-463. [CrossRef]

40. Held, M.; Ilg, R. Update of environmental indicators and energy payback time of CdTe PV systems in Europe. Prog. Photovolt. Res. Appl. 2011, 19, 614-626. [CrossRef]

41. Kim, H.C.; Fthenakis, V.M. Comparative life-cycle energy payback analysis of multi-junction a-SiGe and nanocrystalline/a-Si modules. Prog. Photovolt. Res. Appl. 2011, 19, 228-239. [CrossRef]

42. Mohr, N.J.; Maijer, A.; Huijbregts, M.A.J.; Reijnders, L. Environmental life cycle assessment of roof-integrated flexible amorphous silicon/nanocrystalline silicon solar cell laminate. Prog. Photovolt. Res. Appl. 2012, 21, 802-815. [CrossRef]

43. Kreiger, M.A.; Shonnard, D.R.; Pearce, J.M. Life cycle analysis of silane recycling in amorphous silicon-based solar photovoltaic manufacturing. Resour. Conserv. Recycl. 2013, 70, 44-92. [CrossRef]

44. Giacchetta, G.; Leporini, M.; Marchetti, B. Evaluation of the environmental benefits of new high value process for the management of the end of life of thin film photovoltaic modules. J. Clean. Prod. 2013, 51, 214-224. [CrossRef]

45. Collier, J.; Wu, S.; Apul, D. Life cycle environmental impacts from CZTS (copper zinc tin sulfide) and Zn3P2 (zinc phosphide) thin film PV (photovoltaic) cells. Energy 2014, 74, 314-321. [CrossRef]

46. Bergesen, J.D.; Heath, G.A.; Gibon, T.; Suh, S. Thin-film photovoltaic power generation offers decreasing greenhouse gas emissions and increasing environmental co-benefits in the long term. Environ. Sci. Technol. 2014, 48, 9834-9843. [CrossRef]

47. Lunardi, M.M.; Moore, S.; Alvarez-Gaitan, J.P.; Yan, C.; Hao, X.; Corkish, R. A comparative life cycle assessment of chalcogenide/Si tandem solar modules. Energy 2018, 145, 700-709. [CrossRef]

48. Rajput, P.; Singh, Y.K.; Tiwari, G.N.; Sastry, O.S.; Dubey, S.; Pandey, K. Life cycle assessment of the 3.2kW cadmium telluride (CdTe) photovoltaic system in composite climate of India. Sol. Energy. 2018, 159, 415-422. [CrossRef]

49. Willoughby, A. Solar Cell Materials: Developing Technologies. In Wiley Series in Materials for Electronic $\mathcal{E}$ Optoelectronic Applications; John Wiley \& Sons: Hoboken, NJ, USA, 2014.

50. Green, M.A. Third Generation Photovoltaics: Ultra-High Efficiency at Low Cost. Prog. Photovolt. Res. Appl. 2001, 9, 123-135. [CrossRef]

51. Valverde, G.R.; Cherni, J.A.; Urbina, A. Life cycle analysis of organic photovoltaic technologies. Prog. Photovolt. Res. Appl. 2010, 18, 535-538. [CrossRef]

52. Anctil, A.; Babbitt, C.; Landi, B.; Raffaelle, R.P. Life-cycle assessment of organic solar cell technologies. In Proceedings of the 2010 35th IEEE Photovoltaic Specialists Conference, Honolulu, HI, USA, 20-25 June 2010; pp. 742-747.

53. Sengül, H.; Theis, T.L. An environmental impact assessment of quantum dot photovoltaics (QDPV) from raw material acquisition through use. J. Clean. Prod. 2011, 19, 21-31. [CrossRef]

54. Espinosa, N.; García-Valverde, R.; Urbina, A.; Krebs, F.C. A life cycle analysis of polymer solar cell modules prepared using roll-to-roll methods under ambient conditions. Sol. Energy Mater. Sol. Cells 2011, 95, 1293-1302. [CrossRef]

55. Espinosa, N.; García-Valverde, R.; Urbina, A.; Lenzmann, F.; Manceau, M.; Angmo, D.; Krebs, F.C. Life cycle assessment of ITO-free flexible polymer solar cells prepared by roll-to-roll coating and printing. Sol. Energy Mater. Sol. Cells 2012, 97, 3-13. [CrossRef]

56. Anctil, A.; Fthenakis, V. Life Cycle Assessment of Organic Photovoltaics. Third Gener. Photovolt. 2012, 91-110. [CrossRef]

57. Parisi, M.L.; Maranghi, S.; Sinicropi, A.; Basosi, R. Development of dye sensitized solar cells: A life cycle perspective for the environmental and market potential assessment of a renewable energy technology. Int. J. Heat Technol. 2013, 31, 143-148. [CrossRef]

58. Azzopardi, B.; Mutale, J. Life cycle analysis for future photovoltaic systems using hybrid solar cells. Renew. Sustain. Energy Rev. 2010, 14, 1130-1134. [CrossRef]

59. Espinosa, N.; Krebs, F.C. Life cycle analysis of organic tandem solar cells: When are they warranted? Sol. Energy Mater. Sol Cells 2014, 120, 692-700. [CrossRef] 
60. Parisi, M.L.; Maranghi, S.; Basosi, R. The evolution of the dye sensitized solar cells from Grätzel prototype to up-scaled solar applications: A life cycle assessment approach. Renew. Sustain. Energy Rev. 2014, 39, 124-138. [CrossRef]

61. Parisi, M.L.; Basosi, R. Environmental Life Cycle Analysis of Non Conventional Thin-Film Photovoltaics: The case of Dye-Sensitized solar devices. Energy Secur. Dev. 2015, 193-210. [CrossRef]

62. Tsang, M.P.; Sonnemann, G.W.; Bassani, D.M. Life-cycle assessment of cradle-to-grave opportunities and environmental impacts of organic photovoltaic solar panels compared to conventional technologies. Sol. Energy Mater. Sol. Cells 2016, 156, 37-48. [CrossRef]

63. Celik, I.; Song, Z.; Cimaroli, A.J.; Yan, Y.; Heben, M.J.; Apul, D. Life Cycle Assessment (LCA) of perovskite PV cells projected from lab to fab. Sol. Energy Mater. Sol. Cells 2016, 156, 157-169. [CrossRef]

64. Hengevoss, D.; Baumgartner, C.; Nisato, G.; Hugi, C. Life Cycle Assessment and eco-efficiency of prospective, flexible, tandem organic photovoltaic module. Sol. Energy 2016, 137, 317-327. [CrossRef]

65. Zhang, J.; Gao, X.; Deng, Y.; Zha, Y.; Yuan, C. Comparison of life cycle environmental impacts of different perovskite solar cell systems. Sol. Energy Mater. Sol. Cells 2017, 166, 9-17. [CrossRef]

66. Lunardi, M.M.; Wing, Y.; Ho-Baillie, A.; Alvarez-Gaitan, J.P.; Moore, S.; Corkish, R. A life cycle assessment of perovskite/silicon tandem solar cells. Prog. Photovolt. Res. Appl. 2017, 25, 679-695. [CrossRef]

67. Maranghi, S.; Parisi, M.L.; Basosi, R.; Sinicropi, A. Environmental Profile of the Manufacturing Process of Perovskite Photovoltaics: Harmonization of Life Cycle Assessment Studies. Energies 2019, 12, 3746. [CrossRef]

68. Ito, M.; Komoto, K.; Kurokawa, K. Life-cycle analyses of very-large scale PV systems using six types of PV modules. Curr. Appl. Phys. 2010, 10, S271-S273. [CrossRef]

69. Jungbluth, N. Life cycle assessment of crystalline photovoltaics in the Swiss ecoinvent database. Prog. Photovolt. Res. Appl. 2005, 13, 429-446. [CrossRef]

70. Longo, S.; Cellura, M.; Guarino, F.; Ferraro, M.; Antonucci, V.; Squadrito, G. Life Cycle Assessment of Solid Oxide Fuel Cells and Polymer Electrolyte Membrane Fuel Cells: A Review. In Hydrogen Economy—Supply Chain, Life Cycle Analysis and Energy Transition for Sustainability; Scipioni, A., Manzardo, A., Ren, J., Eds.; Academic Press: Cambridge, MA, USA, 2017; pp. 139-166. Available online: http://hdl.handle.net/10447/ 229145 (accessed on 3 January 2020).

71. Fthenakis, V.; Kim, C.; Frischknecht, R.; Raugei, M.; Sinha, P.; Stucki, M. Life Cycle Inventories and Life Cycle Assessment of Photovoltaic Systems; PVPS Task 12, Report IEA-PVPS T12-02:2011; International Energy Agency (IEA): Paris, France, 2011.

72. ISO. Environmental Management-Life Cycle Assessment_Principles and Framework; 14040; ISO: Geneva, Switzerland, 2006; Available online: https://www.iso.org/standard/38498.html (accessed on 3 January 2020).

73. Cellura, M.; Longo, S.; Mistretta, M. Sensitivity analysis to quantify uncertainty in Life Cycle Assessment: The case study of an Italian tile. Renew. Sustain. Energy Rev. 2011, 15, 4697-4705. [CrossRef]

74. Bravi, M.; Parisi, M.L.; Tiezzi, E.; Basosi, R. Life cycle assessment of advanced technologies for photovoltaic panel production. Int. J. Heat Technol. 2010, 28, 133-140. [CrossRef]

(C) 2020 by the authors. Licensee MDPI, Basel, Switzerland. This article is an open access article distributed under the terms and conditions of the Creative Commons Attribution (CC BY) license (http://creativecommons.org/licenses/by/4.0/). 